\title{
Photo-degradation Effect on Naphtha Octane Number by Using UV Radiation
}

Hayder A.M. Hashim ${ }^{*}$, Haroun A.K Shahad ${ }^{* *}$

* Ministry of Oil, Company of Oil Products Distribution

** Department of Mechanical Engineering, College of Engineering, University of Babylon, Babylon, Iraq

الخملاصة

تم استخدام النفتا في هذا البحث كوقود اختبار حيث تم تعريضها الى الاشعة فوق البنفسية تحت ظروف اختبار مختلفة (تعرض للاشعة فقط ، تعرض للاشعة بوجود التبريد ، تعرض للاشعة بوجود التبريد و العامل المحفز ، تعرض للاشعة بوجود التبريد والعامل المحفز

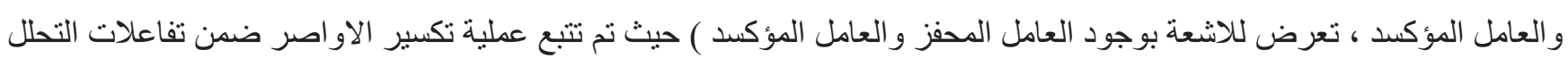
الضوئي، فلوحظ تكسر او اصر عديدة نتيجة امتصاص الاشعة فوق البنفسجية ذات الطاقة العالية، ومن النتائج المتوقعة لهذا التحلل هو تغير العدد الاوكتاني للنفتا .

تم تحضير نماذج من وقود النفتا ومعاملتها تحت ظروف مختلفة باستخدام منظومتين :

• منظومة مفاعل الاشعة (Reactor Unit) : هذه المنظومة تعمل ضمن ضغوط مرتفعة نسبياً ، حيث لوحظ من خلال استخدام

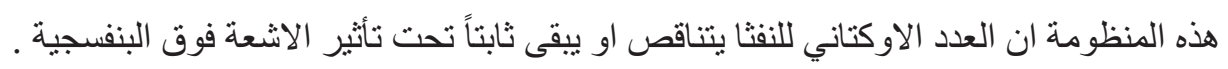
• منظومة خلية الاختبار الزجاجية (Cell Unit) : هذه المنظومة تعمل ضمن الضغط الجوي الاعتيادي حيث لوحظ من خلال

$$
\text { استخدامها ان العدد الاوكتاني للنفتا يتغير بثُلاث سلوكيات (ارتفاع ، انخفاض (لاض ، عدم تغير ). }
$$

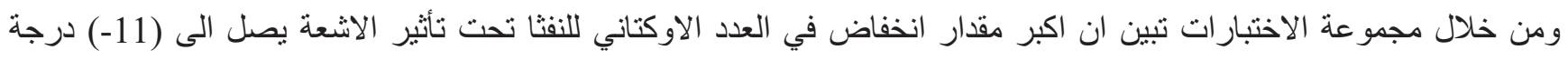
ضمن ظروف تعرض النفا الى الاشعة بوجود التبريد وثنائي اوكسيد التيتانيوم (TiO2) كعامل محفز باستخدام منظومة الخلية الزجاجية

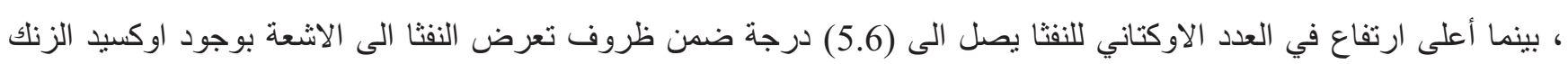
(ZnO) هذه التغيرات الحاصلة في العدد الاوكتاني للنفنا تم استخدام جهاز المطياف Gas chromatography Mass Spectrometry لتحليل عدة نماذج قبل وبعد التعرض للاشعة لرصد التغير الحاصل في نسب المركبات المؤثرة بشكل رئيسي على العدد

$$
\text { الاوكتاني وهي : }
$$

(Isooctane, Benzene, Toluene, P-xylene)

بحيث لوحظ بعد التحليل حدوث زيادة في نسبها في بعض النماذج ونقصان في نماذج اخرى ـ أخيراً نم استخدام جهاز التحليل الطيفي Fourier transform infrared spectroscopy (FTIR) المتكونة والملغية بفعل تأثثر الاشعة وباقي ظروف الاختبار.

الكلمات الدالة: التحلل الضوئي ، النفتا ، العدد الاوكتاني البحثي ، الاشعة فوق البنفسية ، عملية التكسر بتأثير الاشعة 


\section{$\underline{\text { Abstract }}$}

In this work naphtha is exposed to ultraviolet rays under various conditions namely; UV exposure only, UV exposure with cooling, UV exposure with cooling and catalyst, UV exposure with Cooling, Catalyst and Oxidant $\mathrm{O}_{2}$ and $\mathrm{UV}$ exposure with Catalyst and Oxidant $\mathrm{O}_{2}$ to investigate the bonds cracking process (Photo-degradation or photolysis reactions) and its effect on naphtha octane number where several bonds are to be broken due to absorption the high energy of UV radiation. It is expected that naphtha octane number should be changed as a result of the Photo-degradation effect. Samples are prepared and treated with various conditions in a UV Reactor unit under prevailing pressure (elevated pressure). No systematic change in octane number is noticed but the octane number is either decreases or remains constant. Another technique which the cell unit is used. Samples are prepared and treated in the cell unit under atmosphere pressure. Three different behaviors of the change in naphtha octane number are resulted (decreasing, no change and increasing). Maximum decreasing in octane number is (-11 unit) occurred when naphtha is exposed to UV rays with cooling \& $\mathrm{TiO}_{2}$ catalyst in the cell unit, while the maximum increasing is (5.6 unit) occurred when naphtha is exposed to UV rays with $\mathrm{ZnO}$ catalyst \& $(2.1 \mathrm{ml} / \mathrm{min}) \mathrm{O}_{2}$ feeding in the cell unit. In order to understand this behavior Gas chromatography Mass Spectrometry (GCMS) tests are conducted for some samples before and after UV exposure to study the changes in chemical composition of naphtha specially the changes in percentage of compounds that affect the octane number such as: Benzene, Toluene, Isooctane and Pxylene. It is noticed that the percentages of these compounds increased in samples in some tests and decreased in others. Also Fourier Transform Infrared spectroscopy (FTIR) tests are conducted for these samples before and after exposure to find the eliminated or created chemical bonds or functional groups of these bonds.

Keywords Photo-degradation, Naphtha, Research octane number (RON), UV radiation, photolysis process.

\section{Introduction}

Ultraviolet radiation (UV) is part of the non-ionizing region of the electromagnetic spectrum and comprise approximately $8-9 \%$ of the total solar radiation [1] .It is one portion of the electromagnetic spectrum which travel through space. UV radiation is used in many industrial applications such as photo-degradation of hydrocarbon compounds.

In all organic compounds which contain the $\mathrm{C}-\mathrm{H}$ bond and the $\mathrm{C}-\mathrm{C}$ bond, the values of their bond energies and octane number depend on the structures of their molecules. It is well known that 
hydrocarbon fuels with long straight chain molecules have low octane number while fuels with short chain, branched and cyclic molecules have high octane number.

Naphtha is one of hydrocarbon fuels which is produced from crude oil by several methods such as: fractionation of distillates or even crude petroleum, hydrogenation of distillates, solvent extraction, alkylation processes and polymerization of unsaturated olefinic compounds or may be a combination of them. [2]

It is a volatile and flammable fuel with specific gravity of (0.694) at $15 \mathrm{C}^{\circ}$ and boiling range about $\left(30^{\circ} \mathrm{C}-200^{\circ} \mathrm{C}\right)$. It consists of a complex mixture of more than a hundred hydrocarbon compounds with carbon atoms range between $\left(\mathrm{C}_{4}-\mathrm{C}_{15}\right)$. [3]

When naphtha is exposed to UV radiation it will undergo a Photolysis (Photo-dissociation) process [4]. This process causes changes in chemical composition of naphtha and then in its octane number which depends on nature of the contained compounds in naphtha.

There were attempts of subjecting catalysts to varied sources of radiation to enhance their activity. some of these attempts were concentrated on the study of UV rays on the catalyst activity in conversion of unsaturated hydrocarbons. They found that if a catalytic reaction occurs in the presence of UV radiation, substantially complete conversion of reactants is obtained. Thus, they proved that the UV radiation exposure enhances the catalyst activity [5].

Two advantages for using of UV rays with hydrocarbon compounds, one of them is cracking which relates to hydrocarbon bonds and the other is enhancing of the catalyst activity which relates to catalysts in photo-catalysis process [6].

Ali H. A. Rashed et al. (2013)[7], used UV rays to improve the Octane number for Al-Dura product pool (70\% Reformate $+30 \%$ Light Naphtha) in photo-degradation process in the presence of $\mathrm{ZnO}$ catalyst, with different exposure times. They raised the octane number by ( 5 degrees) at ( 8 hours) exposure.

The main aim of the present work is to study the changes in naphtha octane number under UV radiation exposure based on idea of $\mathrm{C}-\mathrm{C}$ and $\mathrm{C}-\mathrm{H}$ bonds breaking and re-structuring.

\section{Experimental Rig and Measurements}

UV Reactor Unit : This unit is manufactured to study the effect of UV exposure on naphtha octane number at different operating pressures (relatively elevated pressures). It consists of the following parts, see figs. $(1 \& 2)$.

a) A cylindrical tank $(0.26 \mathrm{~m}$ diameter, $1 \mathrm{~m}$ height with $50 \mathrm{~L}$ capacity $)$ manufactured from stainless steel to obtain good reflection of UV rays from the tank inner walls. 
b) A motor mounted on the top cover of the tank used to drive the mixer inside the tank at 20 RPM.

c) Three UV lamps each of $\left(100 \mathrm{~W} / \mathrm{m}^{2}\right)$ are inserted in three sleeves manufactured from quartz to obtain optimum transmissivity of UV rays. These sleeves are fixed by Teflon bushes and rubber O-rings in the holes through the top cover of the tank. The rubber O-rings are used to prevent pressure leakage between the sleeve wall and the Teflon bush.

d) Thermometer for temperature recording before and after the test.

e) Pressure gauge to record the tank pressure before and after the test.

f) Safety valve for pressure release.

g) Drainage valve at the base of the tank to empty a charge (a sample) after each test.

h) Cooling water tube $(0.5 \mathrm{~m} \times 0.5 \mathrm{~m} \times 0.7 \mathrm{~m})$ contain cooling water.

i) Submerged water pump (pumping height of $1.8 \mathrm{~m}$ ) to pump the cooling water from cooling tub to the water distributor.

j) Water distributor which is a perforated tubular ring with 17 holes, each hole diameter of (3 $\mathrm{mm})$. It is installed around the tank near the top cover at a height of $(1.1 \mathrm{~m})$ above the submerged water pump and used to distribute the cooling water on the outer surfaces of the tank for cooling if necessary.

UV Cell Unit : This unit operates under atmospheric pressure. It consists of the following parts and auxiliary tools:

a) Two concentric glass vessels are formed as a cell with annulus space used for cooling water, so that the fuel sample is put in the inner vessel.

b) Mixing capsule is immersed inside the cell for sample rotation.

c) Magnetic stirrer is used to rotate the mixing capsule inside the test sample under effect of magnetic field.

d) Cooling system is used to cool the cell during the test and to keep the sample temperature at required value.

e) UV lamp of $\left(75 \mathrm{~W} / \mathrm{m}^{2}\right)$ is fixed by standing over the cell. The lamp is partially enveloped to concentrate the rays in direction of a sample.

f) Air feeder with air flow rate of $(10 \mathrm{ml} / \mathrm{min})$ is used as an Oxygen source.

g) Filtering sheets, graduated cylinder, funnel, electronic balance, burette, thermometer and sample bottle are used. See figs. (3\&4). 


\section{Sample Preparation and Test Procedure}

Naphtha samples of $40 \mathrm{~L}$ for UV Reactor Unit or $(500 \mathrm{ml})$ for UV Cell Unit are prepared. Each sample is mixed with catalyst for $20 \mathrm{~min}$ before UV exposure. The Octane number of the sample is measured either in CFR engine or SHATOX Octane meter, GCMS and FTIR analysis are also conducted for sample before exposure. The temperature of the sample is recorded initially and during the test. Also the pressure inside the UV Reactor tank is recorded initially and during the test. The sample is then exposed to UV rays for a specified period under various conditions. Octane measurement, GCMS and FTIR analysis are conducted after exposure to investigate the changes in the molecular structure caused by the UV exposure.

\section{CFR Engine and SHATOX Octane Meter}

Cooperative Fuel Research (CFR) engine is a 4-stroke, SI engine with a single-cylinder and variable compression ratio used to measure the fuel octane number, see fig. 5. Its Compression Ratio (CR) varies from 4.5 to 16 quickly and accurately by moving the cylinder head with respect to the piston [8] SHATOX Octane Meter is a portable device used to measure the fuel Octane number depending on comparison between characteristics of the test sample and these of standard gasoline stored in the internal memory of its microprocessor [9], see fig. (6). It is calibrated against the CFR engine as shown in fig.(7).

\section{Gas Chromatography Mass Spectrometry (GCMS) Analysis}

It is an apparatus used in the separation, identification and quantification of complex mixtures. The determination of these compounds is very difficult by the standard MS library. Therefore, the retention time was used as an index for the GC qualitative analysis [10]. The changes in the main effective compounds (i.e. compounds that affect the octane number) is determined by comparing the GCMS results before and after UV exposure. The octane number change may be interpreted according to the qualitative and quantitative changes in these compounds.

\section{Fourier Transform Infrared Spectroscopy (FTIR) Analysis}

This apparatus provides crucial information about the molecular structure of organic and inorganic components [11]. The FTIR technique is based on the absorption of IR radiation which occurs when photons transfer to sample molecules. These molecules are excited to a higher energy states [12] causing vibrations of molecular bonds (i.e. bending, stretching, rocking, twisting, wagging and out-of- 
plane deformation). Those excitations occur at varying frequencies (wavenumbers of range about 4000 $-400 \mathrm{~cm}^{-1}$ ) in the IR region of the electromagnetic spectrum.

\section{$\underline{\text { Results and Discussion }}$}

The results are divided into five groups according to the tests conditions:

\section{Naphtha Exposed to UV Rays Only}

The results of these tests are shown in table $1 \&$ fig. 8 . These results show a fluctuating response in the change of naphtha RON when exposed to UV rays only. It decreases to a minimum value of 51.3 after one hour exposure (initial RON 54.5) and then increases to 56 after two hours exposure and then decreases. This fluctuating in Octane number may be attributed to the effect of photolysis (Photodissociation) process.

It is known that the bonds of the branched compounds (iso-paraffin) are weaker than those in the straight chain compounds (n-paraffin) because the branched compound molecules are more compact with less surface area. This means that the intermolecular attractive forces of the branched compounds are smaller. Therefore, the broken bonds due to UV exposure are more in the branched compounds than in the straight chain compounds. In other words, the branches are broken and may be converted into small straight chain compounds. On the other hand, some of the UV energy may be used to break the bonds of straight chain molecules and converted them to branched molecules. As it is known that the RON of straight chain compounds (n-paraffins) is less than that of branched compounds (iso-paraffins), as shown in fig. (9) the net effect of these two restructuring processes may cause the fluctuation in Octane number changes.

\section{Naphtha Exposed to UV Rays with Cooling}

The results of these tests are shown in table (2) \& fig. (10). These results indicate that no change occurs in the Octane number when naphtha is exposed to UV rays with the existence of cooling. An important fact may be concluded in these tests, that the cooling inhabits the Photolysis activity.

In other words, during the UV exposure with temperature rise process the interaction between photons and fuel molecules may occur causing the crack of the bonds of that molecules, whereas the cooling process inhibits that interaction and protects the molecules against the UV exposure effect.

\section{Naphtha Exposed to UV Rays with Cooling and Catalyst}

The results of these tests are shown in table (3) \& fig. (11). These results exhibit that there is sever drop in the RON between $(0.5-1 \mathrm{hr})$ of UV exposure reaching to (-11 unit). After two hours exposure the drop becomes (-6.4 units) only. 
When a catalyst is added to the fuel and exposed to UV rays the photo-catalysis process will occur (i.e. the acceleration of photoreaction in the presence of a catalyst). In this process electrons of catalyst molecules are excited by UV photons and transferred from the valence band to the conduction band, leaving positive holes in the valence band, see fig. (12). The ultimate goal of the process is to have a reaction between the excited electrons with an oxidant to produce a reduced product, and also a reaction between the generated holes with a reductant to produce an oxidized product [13]. If there is no capturer for the electrons in conduction band (active electrons), as in this test, they return quickly to their valence bands and react with the holes (Recombination process).

Titanium dioxide $\left(\mathrm{TiO}_{2}\right)$ and $\mathrm{Zinc}$ oxide $(\mathrm{ZnO})$ are used as a suitable catalysts. They are both semiconductors each of them have a band gap energy of (3.2 eV) [14]. The fluctuation in the RON change that is exhibited in these results may be attributed to the recombination process which occurs in the absence of capturer. Therefore only the photolysis effect will be existed.

\section{$\underline{\text { 4.Naphtha Exposed to UV Rays with Cooling, Catalyst and Oxidant } \mathrm{O}_{2}}$}

Oxygen is known to act as a capturer of electrons that exist in the conduction band to generate radicals which may lead to production of high RON compounds. Air is used as a source of oxygen in this work in the presence of catalyst to improve RON of naphtha. Two tests are carried out with air flow rate of $10 \mathrm{ml} / \mathrm{min}$ (oxygen flow rate of $2.1 \mathrm{ml} / \mathrm{min}$ ). In the first test $\mathrm{TiO}_{2}$ is used as catalyst and the results are shown in table (4) and fig. (13) while in the second test $\mathrm{ZnO}$ is used as catalyst and the results are shown in table (5) and fig. (14).

The results of $\mathrm{TiO}_{2}$ test show a decrease in the RON, while the results of $\mathrm{ZnO}$ test show an increase in the $\mathrm{RON}$ value. This means that $\mathrm{ZnO}$ is more effective than $\mathrm{TiO}_{2}$ in photo-catalysis process with the presence of $\mathrm{O}_{2}$ oxidant which acts as a capturer for the active electrons in conduction band of catalyst molecules.

\section{Naphtha Exposed to UV Rays with Catalyst and Oxidant $\mathrm{O}_{2}$}

To investigate the effect of cooling on the photo-catalysis process samples with $\mathrm{ZnO}$ catalyst and oxidant are exposed to UV rays in the absence of cooling. The oxidant (which oxygen) flow rate oxidant. $2.1 \mathrm{ml} / \mathrm{min}$.

The results are shown in table (6) and fig. (15). These results show a fluctuating decrease in octane number initially until two hours exposure then the octane number begins to increase. A maximum increase in octane number of 5.6 units occurs at $4 \mathrm{hrs}$ exposure. At longer exposure time the RON 
value decreases again. In these tests the oxidant reacts with the excited electrons in conduction band generating radicals (reduced product) in photo-catalysis process. These radicals may lead to production of high RON compounds.

\section{GCMS Tests}

Due to the large number of compounds contained in naphtha, it is difficult to follow all changes in the chemical composition of the sample. It is known that the aromatic compounds have high RON values in comparison with the other hydrocarbons groups [15] as shown in fig. (9). Therefore, the GCMS test is performed to understand the changes in aromatic group in addition to the iso-paraffin (Isooctane) which may be the cause of changes in the RON values.

The GCMS tests are performed on a sample of naphtha before and after ( $2 \mathrm{hrs}$ ) of exposure of UV rays as shown in figs. (16\&17) tables (7\&8). The RON change is (6.4 decrease) with the conditions mentioned in table (3).

Table (9) \& fig. (18) Show the percentage change in the main effective four compounds. The results show that the Isooctane is generated after UV exposure test and the Toluene percentage is increased. Whereas, the percentages of Benzene is decreased and P-xylene is vanished. The RON decrease which happened in the sample after UV exposure test may be attributed to the changes of the effective compounds. Specially, after taking into account the RON values of these effective compounds as mentioned in table (10).

GCMS tests are also performed on a sample which shows an increase in octane number. The tests are performed before and after three hours exposure of UV rays and the result is shown in figs. (19 \& 20) and tables (11\&12). The RON change of this sample is 2.1 unit increase with the mentioned conditions in table (6).

Table (13) and fig. (21) show the percentage change in the main effective four compounds which are Isooctane, Benzene, P-xylene and Toluene. The results show that there are increases in the percentages of Isooctane, Benzene and P-xylene, while the Toluene is vanished completely. The increase in RON value which happened in this sample may be attributed to the increase in the percentage of the effective four compounds. specially, after taking into account the high RON values of these effective compounds.

\section{FTIR Tests}

FTIR tests are conducted before and after UV exposure for the sample which shows a decrease in RON which is the same as in the GCMS and the results exhibit the following changes shown in figs. 22 \& 23. The following changes are noted: 
At frequency of $\left(2175.5 \mathrm{~cm}^{-1}\right),(\mathrm{C} \equiv \mathrm{C})$ bond from (alkynes) functional group is existed before UV exposure, but it is not apparent after the exposure.

At frequency of $\left(2229.17 \mathrm{~cm}^{-1}\right),(\mathrm{C} \equiv \mathrm{C})$ bond from (alkynes) functional group appears after the exposure.

This test is also carried out on the same RON increasing sample that mentioned in the GCMS test. Figs. (22 \& 24) show the results of the FTIR test before and after UV exposure respectively. The results exhibited the following changes.

At frequency of (2175.5 cm-1), bond from (alkynes) functional group and at frequency of (1350.86 cm1), bond from (alkanes) functional group are existed before UV exposure, but they are eliminated after the exposure.

At frequency of (1404.94 cm-1), bond from (aromatics) functional group and at frequency of (706.14), bond from (aromatics) functional group are created after the exposure.

\section{Conclusions}

The following conclusions can be drawn:

1. Photolysis effect under UV exposure only. This effect causes a fluctuating change in the octane number due to the difference in the broken bonds numbers between the straight chain and branched.

2. Cooling process inhabits effect under UV exposure. This effect causes no effect in the octane number.

3. UV exposure, cooling and catalyst also causes a fluctuating change in the octane number.

4. Using $\mathrm{ZnO}$ catalyst with UV exposure, cooling and oxidant gives positive octane number change as the results of photo-catalysis process while using $\mathrm{TiO}_{2}$ catalyst gives negative change.

5. Photo-catalysis effect under $\mathrm{UV}$ exposure, $\mathrm{ZnO}$ catalyst and $\mathrm{O}_{2}$ oxidant produces an increase in octane number due to production of high RON compounds. 


\section{$\underline{\text { References }}$}

1. Meseret Tesema Terfa, et. al., 2014, (Effects of UV Radiation on Growth and Postharvest Characteristics of Three Pot Rose Cultivars Grown at Different Altitudes), Elsevier, Journal of Scientia Horticulturae, Vol.(178), pp (184-191).

2. Amna Kamal-eldin Tag-elsir et. al., 2013, (Production of gasoline from light naphtha by isomerization), University of Khartoum, Department of Chemical Engineering.

3. Marcio V. Reboucas, et. al., 2003, (Arsenic determination in naphtha by electrothermal atomic absorption spectrometry after preconcentration using multiple injections), J. Anal. At. Spectrom., Vol. (18), pp(1267-1273).

4. Anuvab Mandal, et. al., 2015, (Photoabsorption and photodissociation studies of dimethyl sulphoxide (DMSO) in the 35,000-80,000 $\mathrm{cm}^{-1}$ region using synchrotron radiation), Elsevier, Journal of Quantitative Spectroscopy and Radiative Transfer, Vol. (156), pp (47-57).

5. Francis William Kirsch, Patented Apr. 6, 1971, (Conversion of Unsaturated Hydrocacarbons in The Presence of a Catalyst and Ultraviolet Radiation), United States Patent office.

6. Hayder A. M. Hashim, 2017, (Improving Fuel Octane Number by Using Ultraviolet Rays), Thesis Submitted to mechanical Engineering at University of Babylon.

7. Ali H. Ali Rashed, et. al., July, 2013, (Improving of Gasoline Octane Number by Using UV Rays in Photo Degradation Process), Journal of petroleum research \& studies, ISSN-22205381, NO.7, pp(A1 - A10).

8. Giuseppe Genchi and Emiliano Pipitone, (November 2014), (Octane Rating of Natural GasGasoline Mixtures on CFR Engine), SAE Int. J. Fuels Lubr., Vol. (7), Issue 3.

9. Munther A. Mussa, 17th to 18th March 2016, (Experimental Investigation of Adding Albocarbon on Otto Engine Efficiency), 4th International Conference On Advances in Civil, Structural and Mechanical Engineering - CSM , Birmingham, United Kingdom.

10. Isabel Duarte Coutinho, et. al., oct./ dec., 2009, (Gas Chromatography-Mass Spectrometry (GCMS) and evaluation of antioxidant and antimicrobial activities of essential oil of Campomanesia adamantium) (Cambess.) O. Berg (Guavira), Brazilian Journal of Pharmaceutical Sciences, No.4, Vol.(45).

11.Yanyan Chen, et. al., 2015, (Applications of Micro-Fourier Transform Infrared Spectroscopy (FTIR) in the Geological Sciences-A Review), Int. J. Mol. Sci., Vol. (16), pp (30223-30250). 
12.Parikh S. J. and Chorover J. 2005, (FTIR spectroscopic study of biogenic Mn-oxide formation by Pseudomonas putida, GB-1. Geomicrobiol. J.), Vol.(22), pp (207-218).

13. Gaëlle Carré, et. al., April 2014, ( $\mathrm{TiO}_{2}$ Photocatalysis Damages Lipids and Proteins in Escherichia coli, Applied and Environmental Microbiology), Vol. (80), No. (8), pp(2573-2581).

14.Kaur S., 2007, (Light Induced Oxidative Degradation Studies of Organic Dyes and Their Intermediates), Thapar University, India.

15. Albahri T. A., et. al., 2002, (Octane Number and Aniline Point of Petroleum Fuels), Journal of Fuel Chemistry Division Preprints Vol. 47(2), 710.

16.An American National Standard (Standard Test Method for Research Octane Number of SparkIgnition Engine Fuel), ASTM International, 100 Barr Harbor Drive, PO Box C700, West Conshohocken, Designation: D 2699 - 04a.

17.Julius S., 1990, (Octane-Enhancing Zeolitic FCC Catalysts, Scientific and Technical Aspects), Vol. 42, CRC Press. 


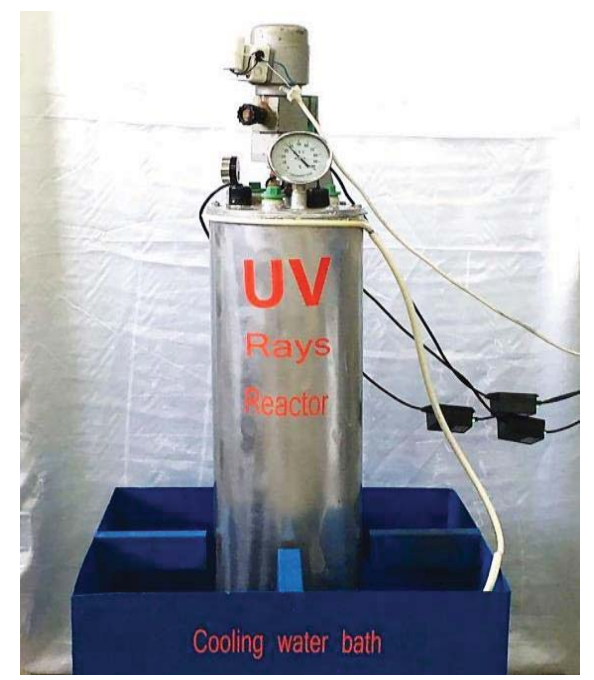

Fig. (1) Reactor Unit.

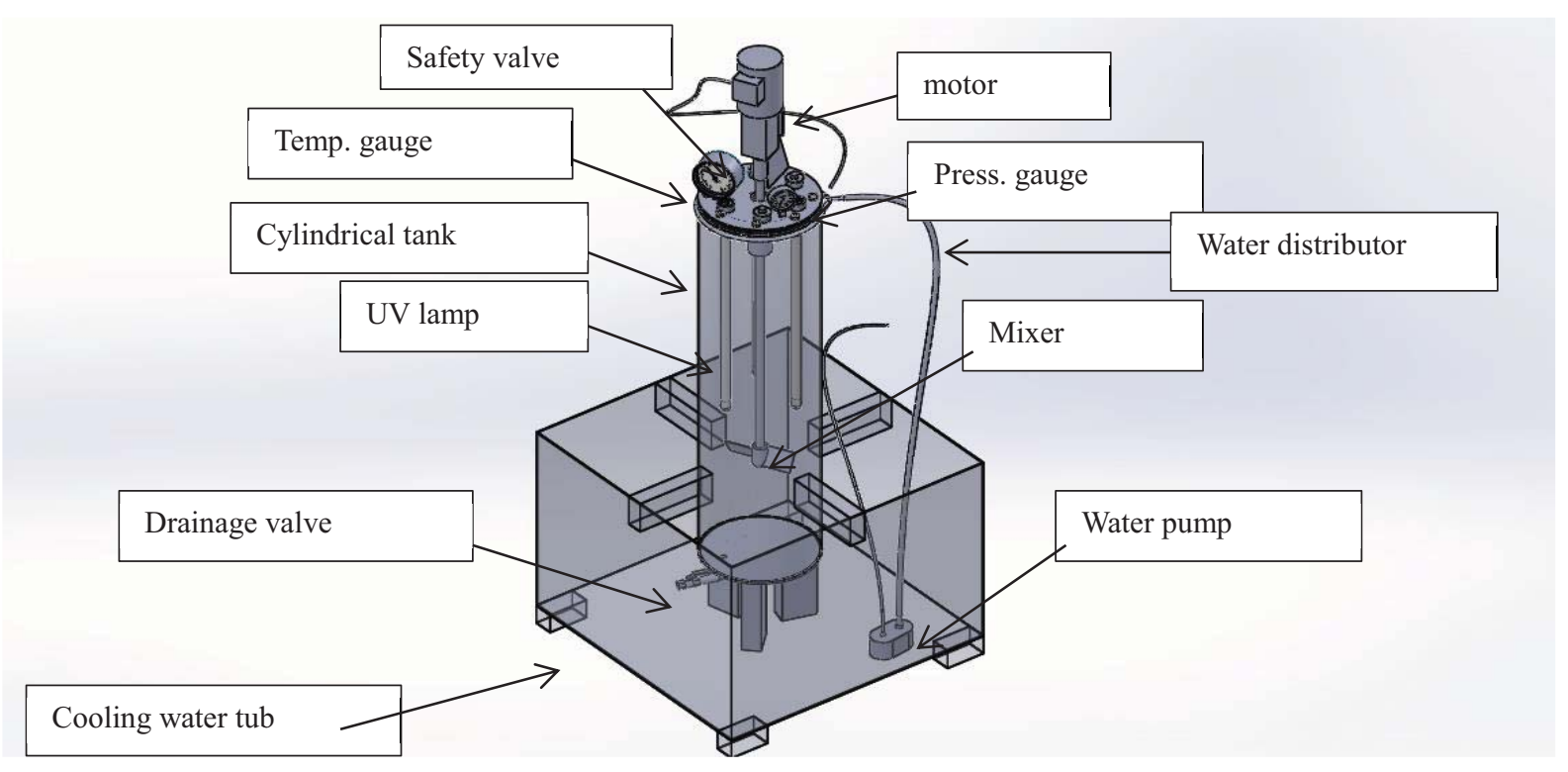

Fig. (2) Schematic Reactor Unit. 


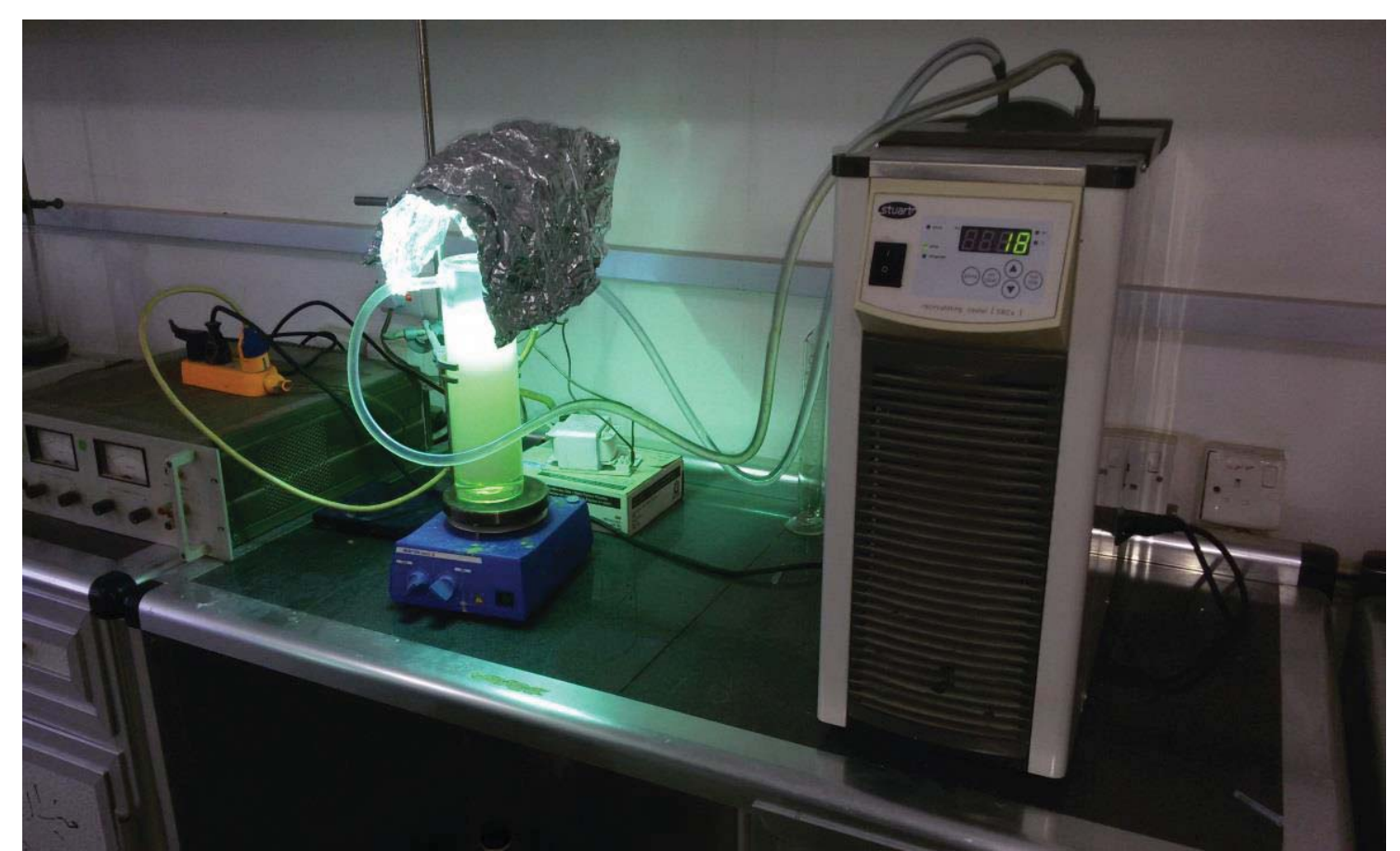

Fig. (3) The Cell Unit.

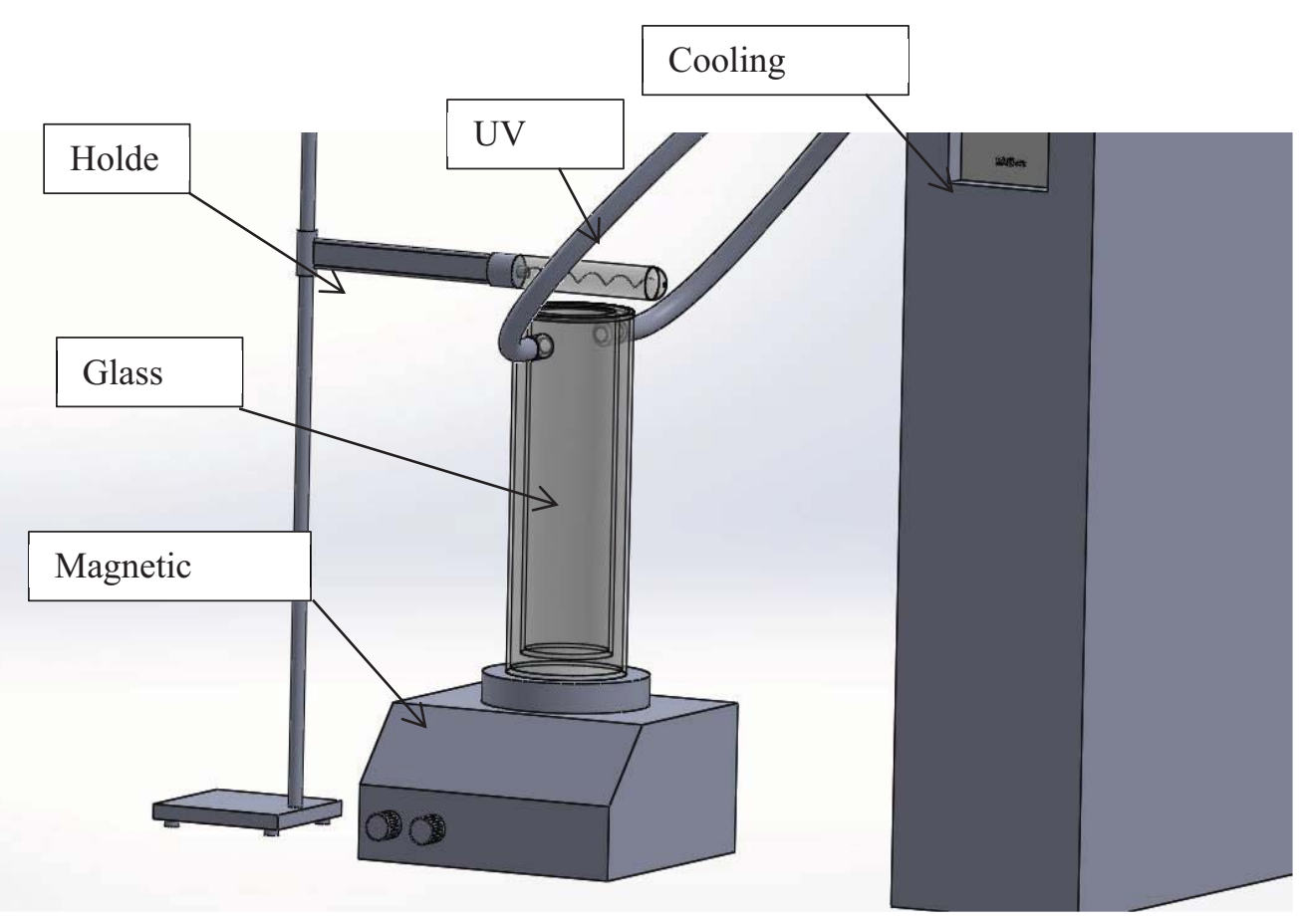

Fig. (4) Schematic Cell Unit. 

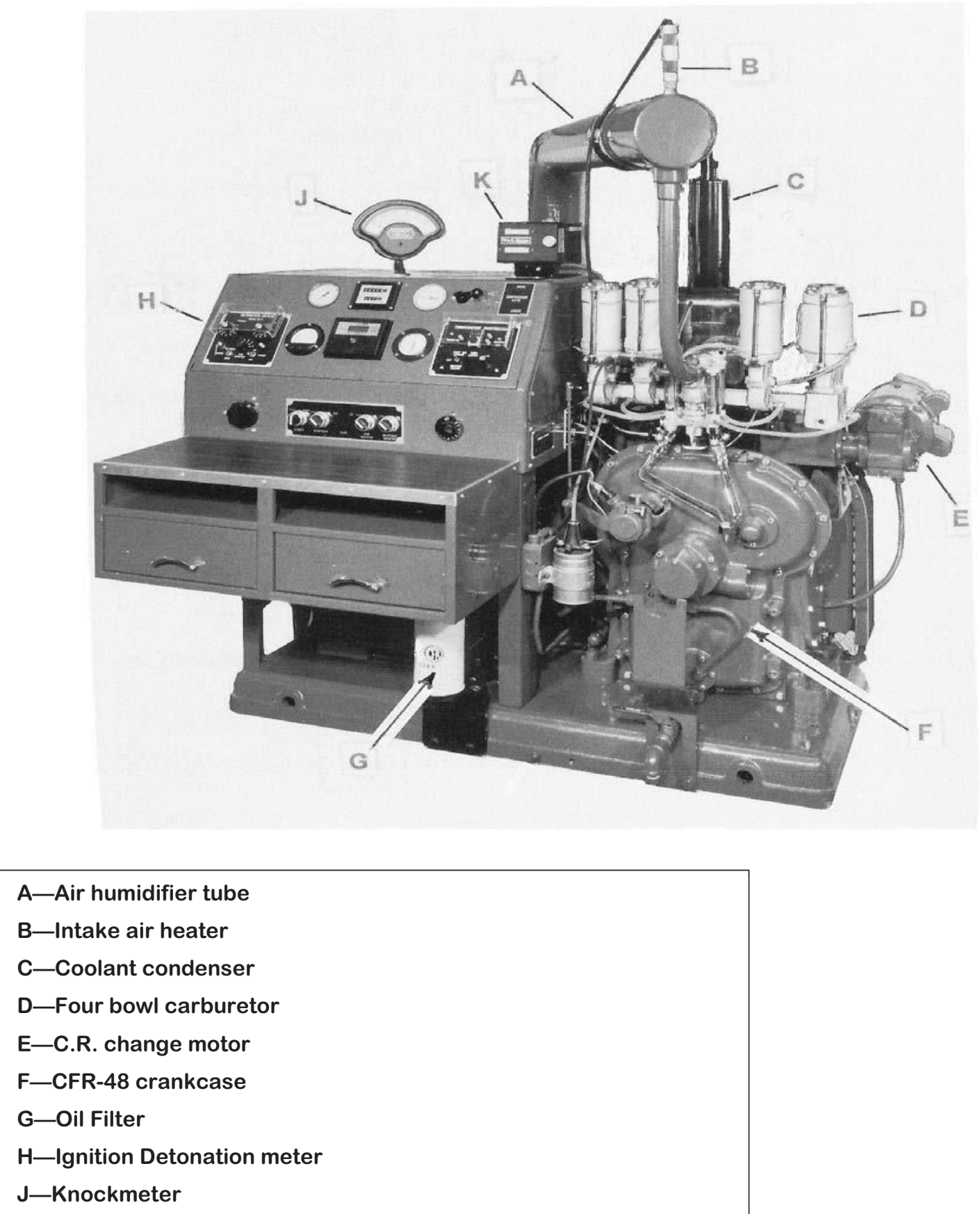

Fig. (5) CFR Engine for RON \& MON Testing [16]. 


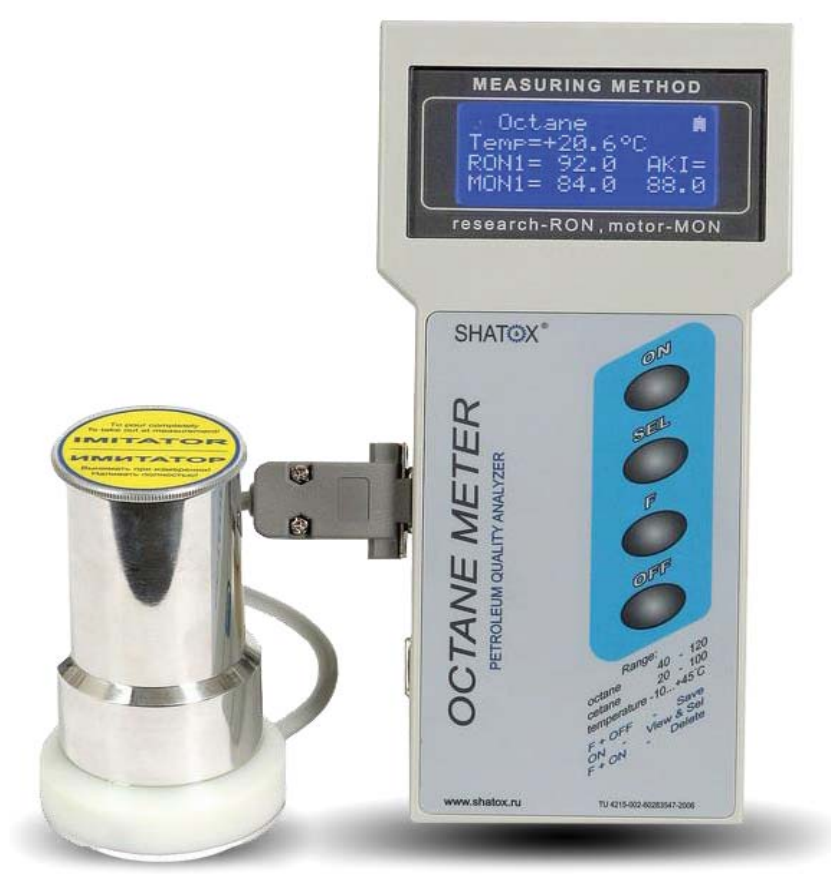

Fig. (6) SHATOX Octane Meter

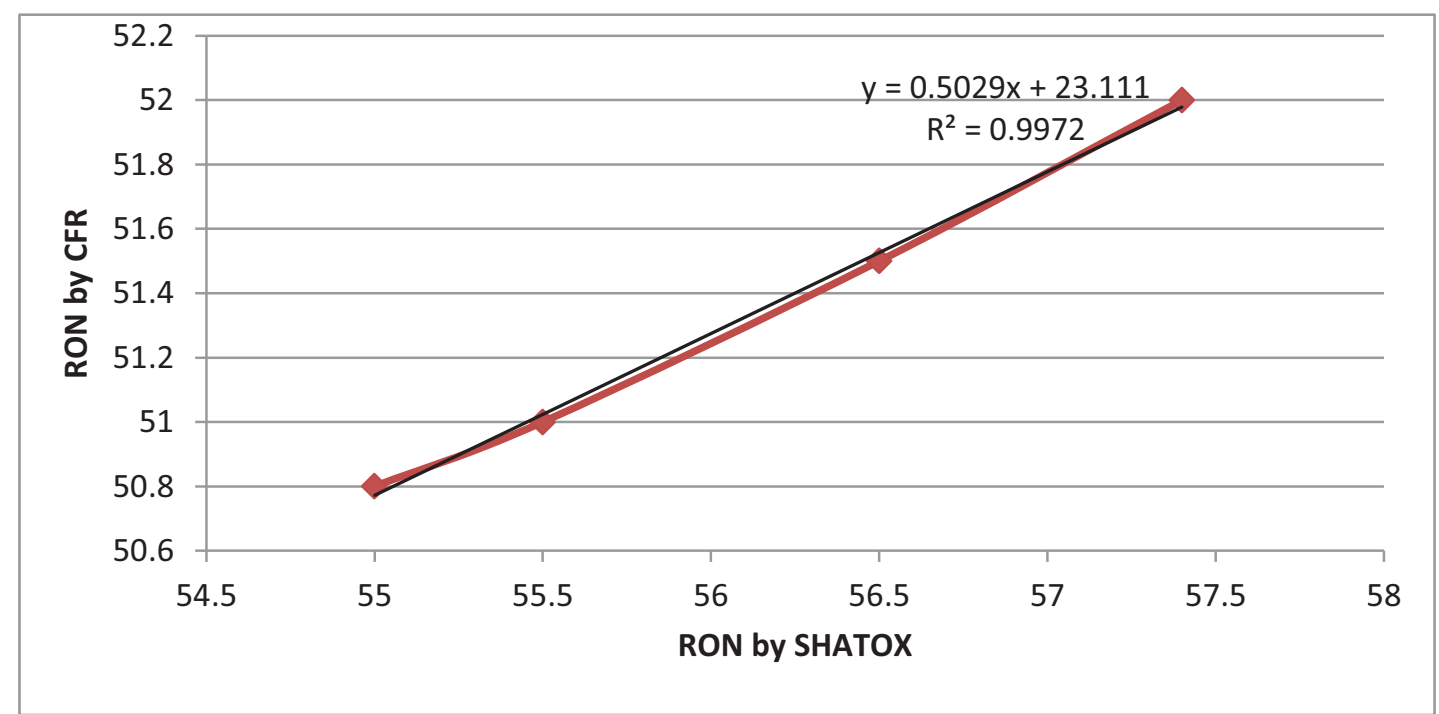

Fig. (7) Calibration of SHATOX Octane Meter. 


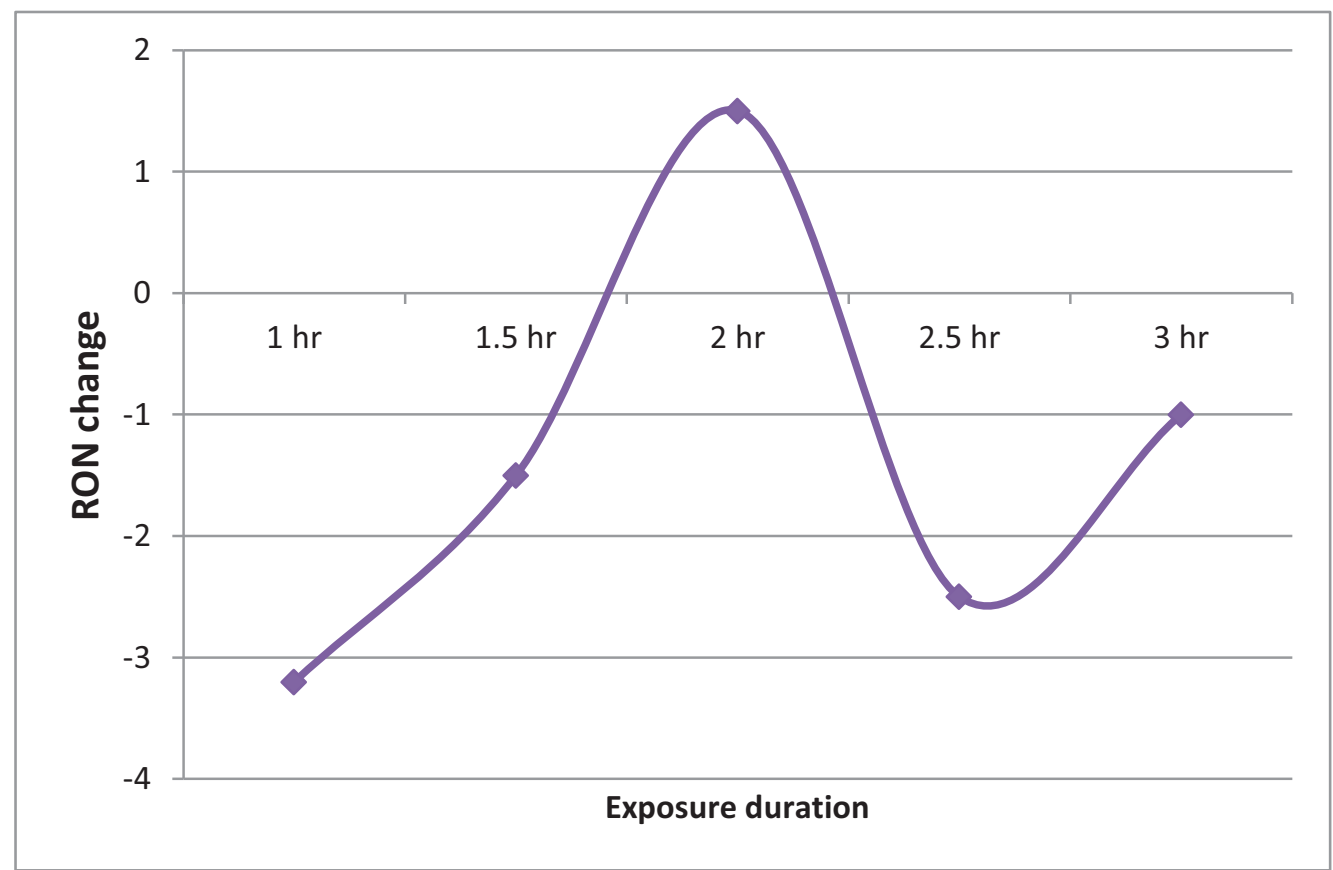

Fig. (8) Results Of Naphtha Exposed To UV Radiation.

Table (1) Results Of Naphtha Exposed To UV Radiation.

\begin{tabular}{|c|c|c|c|c|c|c|c|}
\hline \multirow[t]{2}{*}{$\begin{array}{c}\text { Conditions } \\
\text { of test }\end{array}$} & \multirow{2}{*}{$\begin{array}{c}\text { Time } \\
\text { of test } \\
(\mathrm{hr})\end{array}$} & \multirow{2}{*}{$\begin{array}{c}\text { Pressure } \\
\text { increase } \\
\text { (bar) }\end{array}$} & \multicolumn{2}{|c|}{$\begin{array}{c}\text { Temperature } \\
\qquad\left(\mathrm{C}^{0}\right)\end{array}$} & \multirow{2}{*}{$\begin{array}{c}\text { RON } \\
\text { before } \\
\text { test }\end{array}$} & \multirow{2}{*}{$\begin{array}{l}\text { RON } \\
\text { after } \\
\text { test }\end{array}$} & \multirow[t]{2}{*}{$\begin{array}{l}\text { RON } \\
\text { change }\end{array}$} \\
\hline & & & $\begin{array}{c}\text { Before } \\
\text { test }\end{array}$ & $\begin{array}{r}\text { After } \\
\text { test }\end{array}$ & & & \\
\hline \multirow{5}{*}{$\begin{array}{l}\text { Naphtha } \\
\text { exposed to UV } \\
\text { radiation only . }\end{array}$} & 1 & 0.18 & 23 & 35 & 54.5 & 51.3 & -3.2 \\
\hline & 1.5 & 0.21 & 24 & 35 & 54.5 & 53 & -1.5 \\
\hline & 2 & 0.26 & 23 & 37 & 54.5 & 56 & +1.5 \\
\hline & 2.5 & 0.28 & 23 & 38 & 54.5 & 52 & -2.5 \\
\hline & 3 & 0.31 & 22 & 38 & 54.5 & 53.5 & -1 \\
\hline
\end{tabular}


Journal of Petroleum Research \& Studies

(JPR\&S)

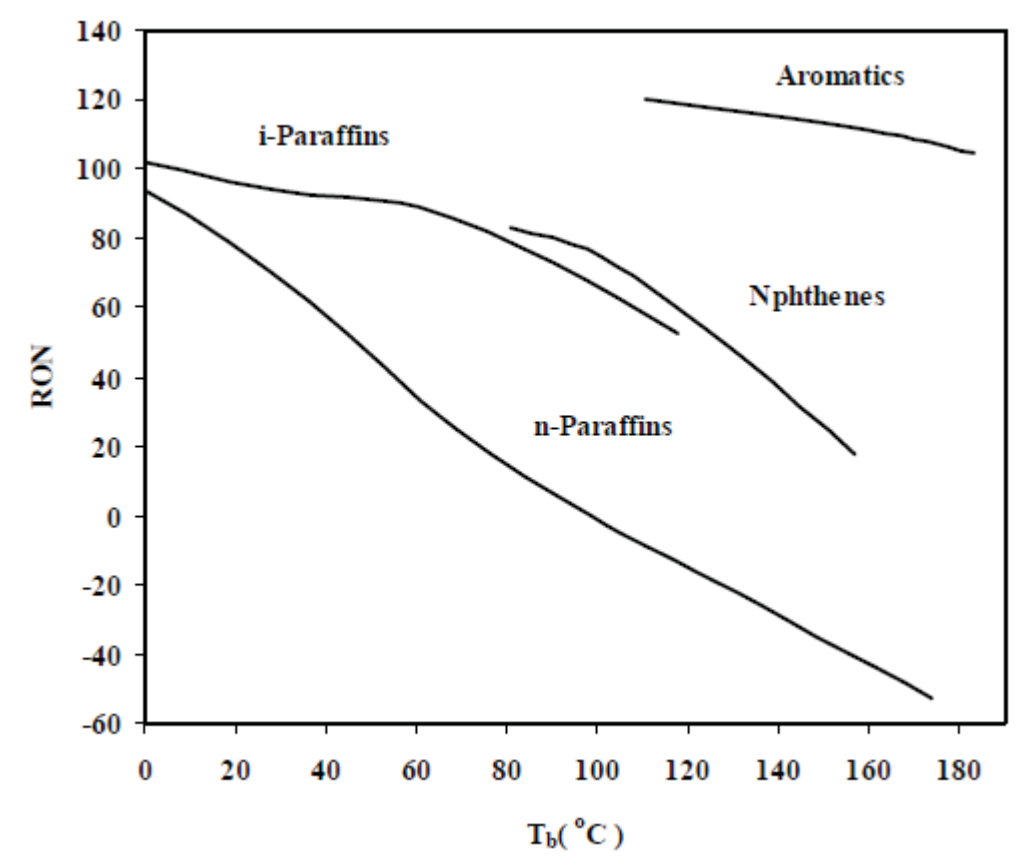

Fig. (9) Research Octane Number of Pure Hydrocarbons from Different Families [15].

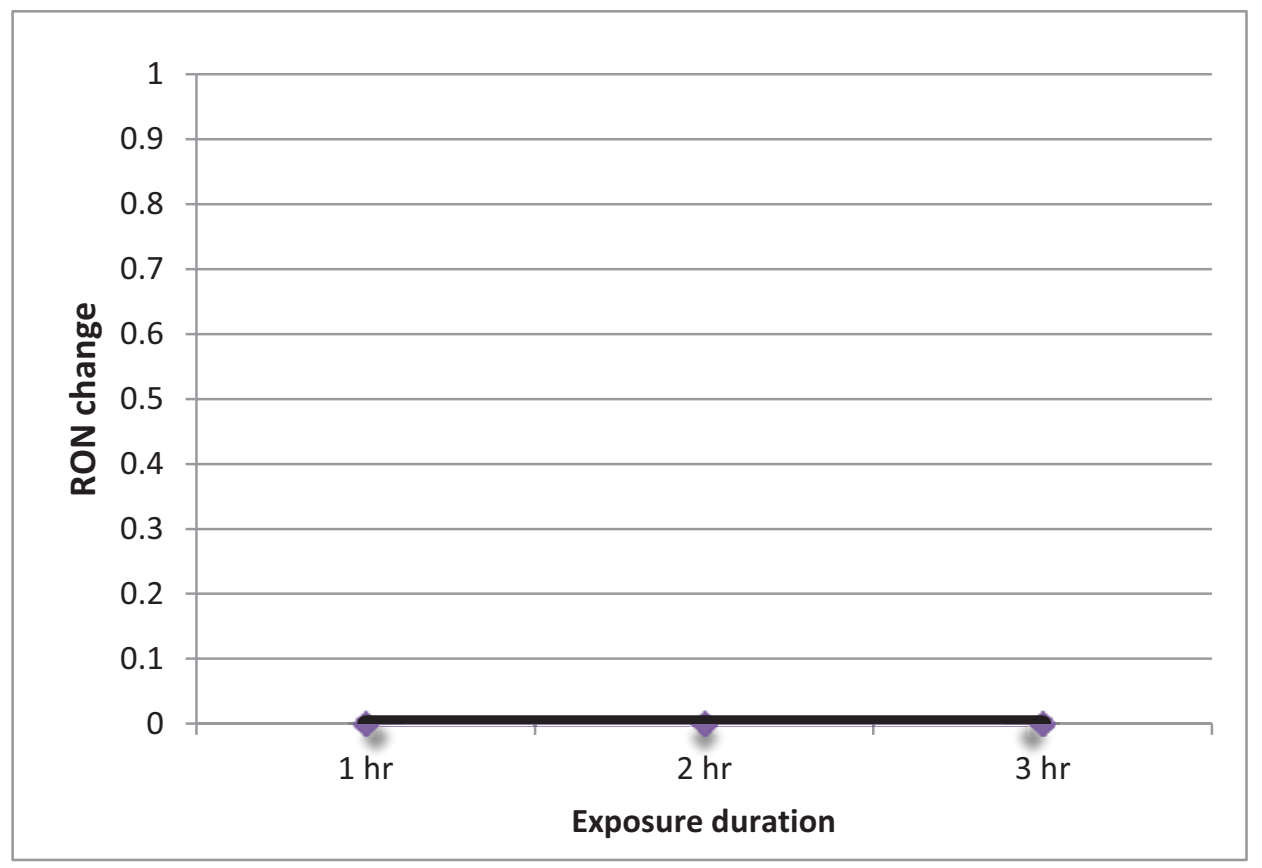

Fig. (10) Results Of Naphtha Exposed To UV Radiation With Cooling. 
Table (2) Results Of Naphtha Exposed To UV Radiation With Cooling.

\begin{tabular}{|c|c|c|c|c|c|c|c|}
\hline \multirow[t]{2}{*}{$\begin{array}{c}\text { Conditions of } \\
\text { test }\end{array}$} & \multirow{2}{*}{$\begin{array}{c}\text { Time of } \\
\text { test } \\
\text { (hr) }\end{array}$} & \multirow{2}{*}{$\begin{array}{c}\text { Pressure } \\
\text { increase } \\
\text { (bar) }\end{array}$} & \multicolumn{2}{|c|}{$\begin{array}{c}\text { Temperature } \\
\qquad\left(C^{\circ}\right)\end{array}$} & \multirow{2}{*}{$\begin{array}{c}\text { RON } \\
\text { before } \\
\text { test }\end{array}$} & \multirow{2}{*}{$\begin{array}{l}\text { RON } \\
\text { after } \\
\text { test }\end{array}$} & \multirow[t]{2}{*}{$\begin{array}{l}\text { RON } \\
\text { change }\end{array}$} \\
\hline & & & $\begin{array}{c}\text { Before } \\
\text { test }\end{array}$ & $\begin{array}{c}\text { After } \\
\text { test }\end{array}$ & & & \\
\hline \multirow{3}{*}{$\begin{array}{l}\text { Naphtha } \\
\text { exposed } \\
\text { to UV radiation } \\
\text { with cooling }\end{array}$} & 1 & 0.16 & 24 & 25.5 & 54.5 & 54.5 & $\begin{array}{c}\text { No } \\
\text { change }\end{array}$ \\
\hline & 2 & 0.17 & 24 & 25.5 & 54.5 & 54.5 & $\begin{array}{c}\text { No } \\
\text { change }\end{array}$ \\
\hline & 3 & 0.19 & 24 & 25.5 & 54.5 & 54.5 & $\begin{array}{c}\text { No } \\
\text { change }\end{array}$ \\
\hline
\end{tabular}

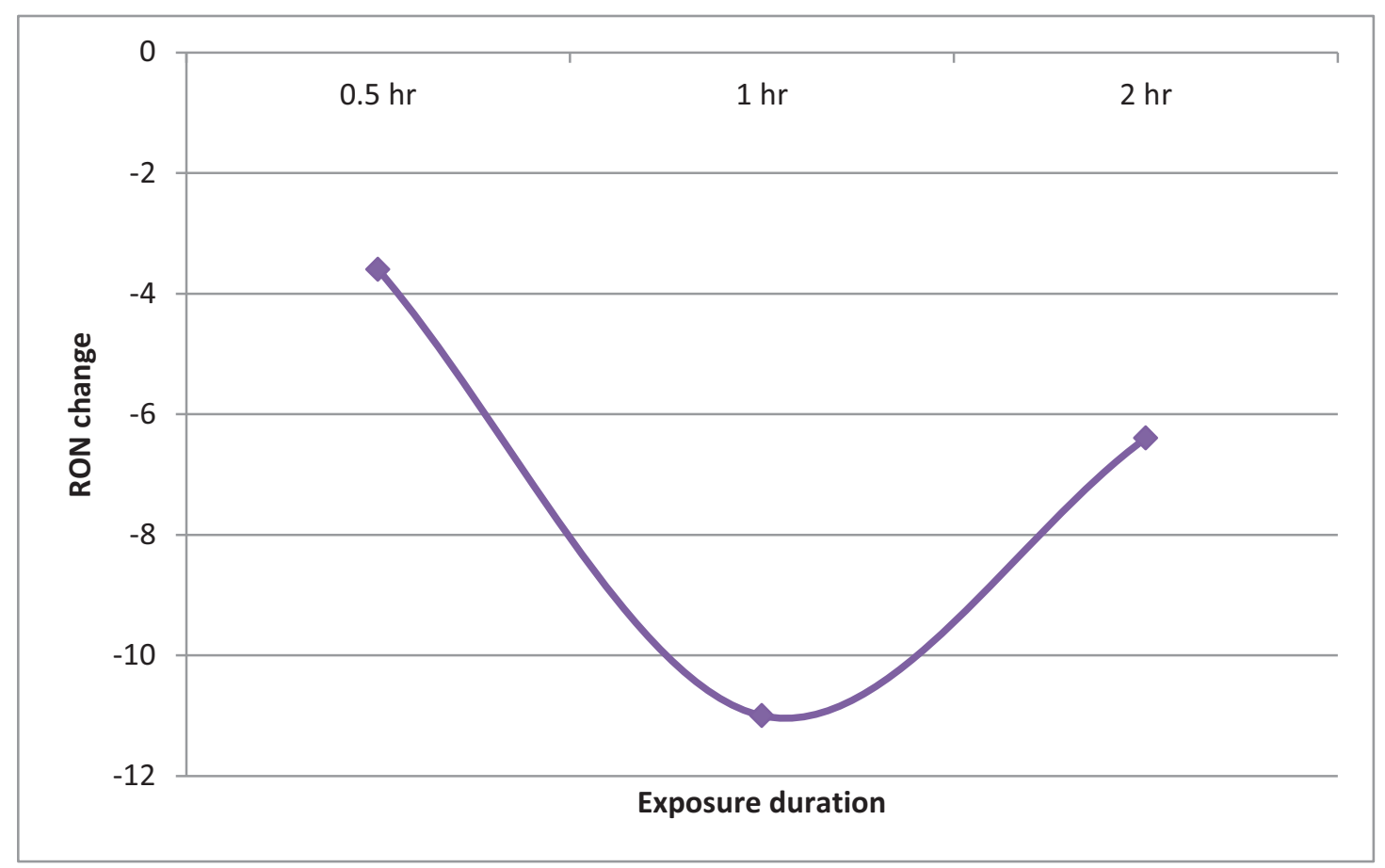

Fig. (11) Results of Naphtha Exposed To UV Radiation With Cooling \& $\mathrm{TiO}_{2}$ Catalyst. 
Table (3) Results of naphtha exposed to UV radiation with cooling \& $\mathrm{TiO}_{2}$ catalyst.

\begin{tabular}{|c|c|c|c|c|c|c|c|}
\hline \multirow[t]{2}{*}{ Conditions of test } & \multirow{2}{*}{$\begin{array}{c}\text { Time } \\
\text { of test } \\
\text { (hr) }\end{array}$} & \multirow{2}{*}{$\begin{array}{c}\text { Pressure } \\
\text { increase } \\
\text { (bar) }\end{array}$} & \multicolumn{2}{|c|}{$\begin{array}{c}\text { Temperature } \\
\qquad\left(\mathrm{C}^{\circ}\right)\end{array}$} & \multirow{2}{*}{$\begin{array}{c}\text { RON } \\
\text { before } \\
\text { test }\end{array}$} & \multirow{2}{*}{$\begin{array}{l}\text { RON } \\
\text { after } \\
\text { test }\end{array}$} & \multirow[t]{2}{*}{$\begin{array}{c}\text { RON } \\
\text { change }\end{array}$} \\
\hline & & & $\begin{array}{c}\text { Before } \\
\text { test }\end{array}$ & $\begin{array}{c}\text { After } \\
\text { test }\end{array}$ & & & \\
\hline \multirow{3}{*}{$\begin{array}{l}\text { Naphtha exposed } \\
\text { to UV radiation } \\
\text { with cooling } \\
\& \mathrm{TiO}_{2} \text { catalyst }\end{array}$} & 0.5 & 0.11 & 25 & 25 & 54.5 & 50.9 & -3.6 \\
\hline & 1 & 0.15 & 25 & 25 & 54.5 & 43.5 & -11 \\
\hline & 2 & 0.17 & 25 & 25 & 54.5 & 48.1 & -6.4 \\
\hline
\end{tabular}

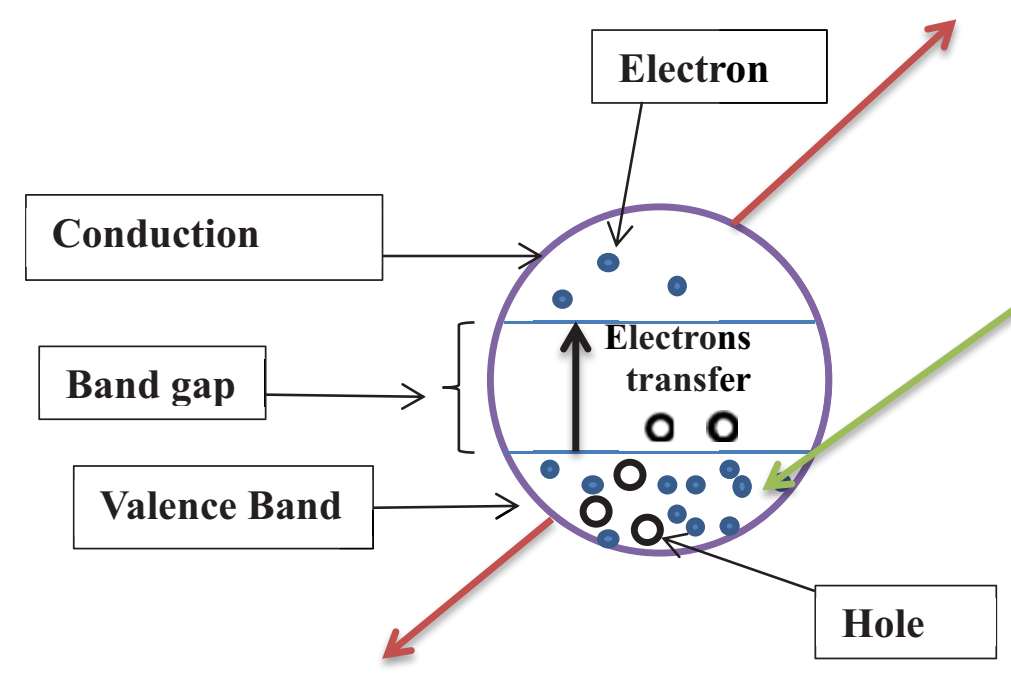

Fig. (12) Photo-Catalysis Process 


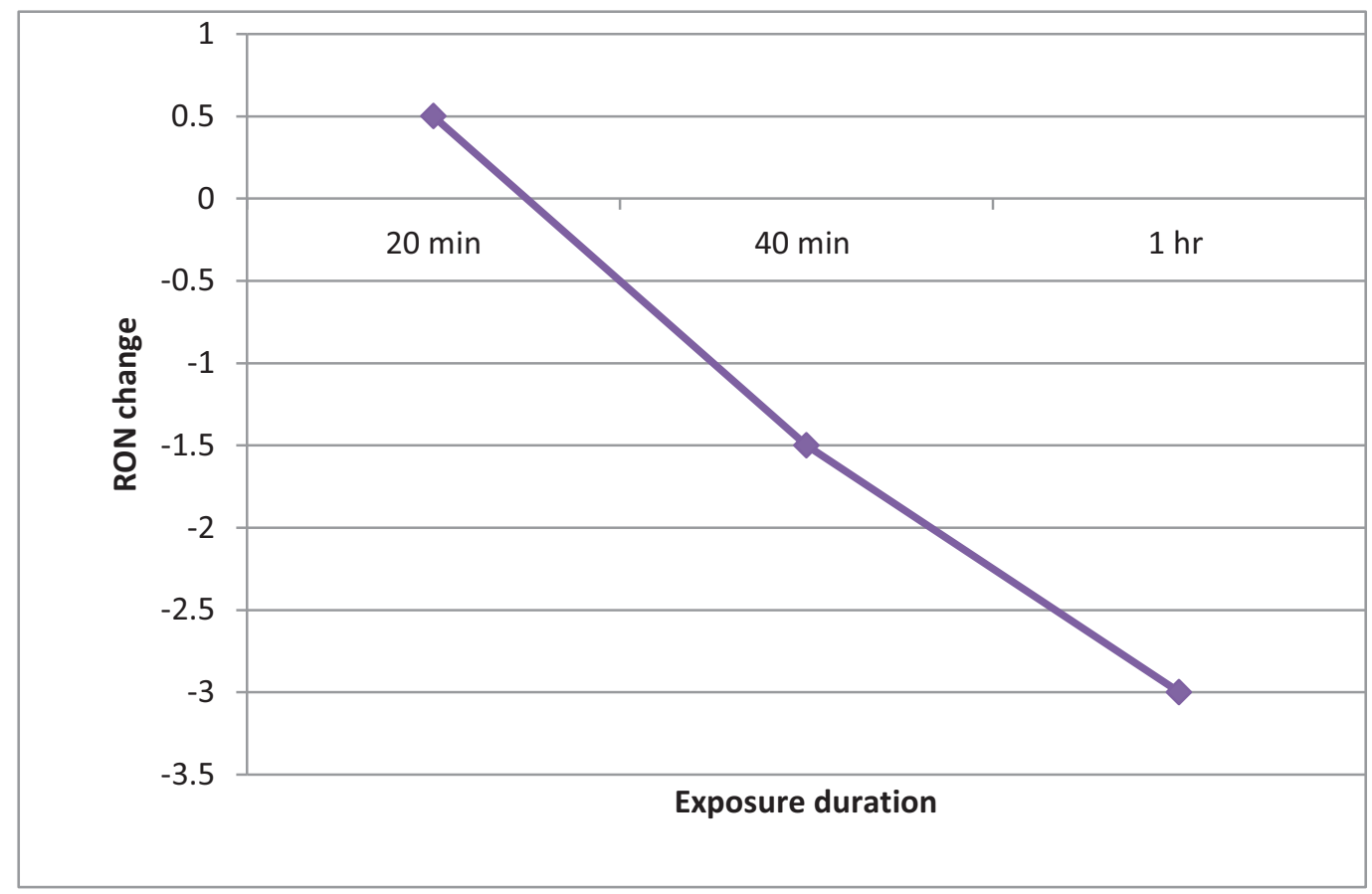

Fig. (13) Results of naphtha exposed to UV rays with cooling, $\mathrm{TiO}_{2}$ catalyst \& $(2.1 \mathrm{ml} / \mathrm{min}) \mathrm{O}_{2}$ in the cell unit.

Table (4) Results of naphtha exposed to $\mathrm{UV}$ rays with cooling, $\mathrm{TiO}_{2}$ catalyst $\&(2.1 \mathrm{ml} / \mathrm{min}) \mathrm{O}_{2}$ in the cell unit.

\begin{tabular}{|c|c|c|c|c|c|c|c|}
\hline \multirow[t]{2}{*}{ Conditions of test } & \multirow[t]{2}{*}{$\begin{array}{c}\text { Time of } \\
\text { test }\end{array}$} & \multirow{2}{*}{$\begin{array}{c}\text { Pressure } \\
\text { increase } \\
\text { (bar) }\end{array}$} & \multicolumn{2}{|c|}{$\begin{array}{c}\text { Temperature } \\
\left(\mathrm{C}^{\circ}\right)\end{array}$} & \multirow{2}{*}{$\begin{array}{c}\text { RON } \\
\text { before } \\
\text { test }\end{array}$} & \multirow{2}{*}{$\begin{array}{r}\text { RON } \\
\text { after } \\
\text { test }\end{array}$} & \multirow[t]{2}{*}{$\begin{array}{l}\text { RON } \\
\text { change }\end{array}$} \\
\hline & & & $\begin{array}{c}\text { Before } \\
\text { test }\end{array}$ & $\begin{array}{c}\text { After } \\
\text { test }\end{array}$ & & & \\
\hline \multirow{3}{*}{$\begin{array}{l}\text { Naphtha exposed to } \\
\text { UV lamp of }\left(75 \mathrm{~W} / \mathrm{m}^{2}\right) \\
\text { with cooling, } \mathrm{TiO}_{2} \\
\text { catalyst \& }(2.1 \\
\mathrm{ml} / \mathrm{min}) \mathrm{O}_{2} .\end{array}$} & $20 \mathrm{~min}$ & 0 & 25 & 25 & 51.2 & 51.7 & +0.5 \\
\hline & $40 \mathrm{~min}$ & 0 & 25 & 25 & 51.2 & 49.7 & -1.5 \\
\hline & $1 \mathrm{hr}$ & 0 & 25 & 25 & 51.2 & 48.2 & -3 \\
\hline
\end{tabular}




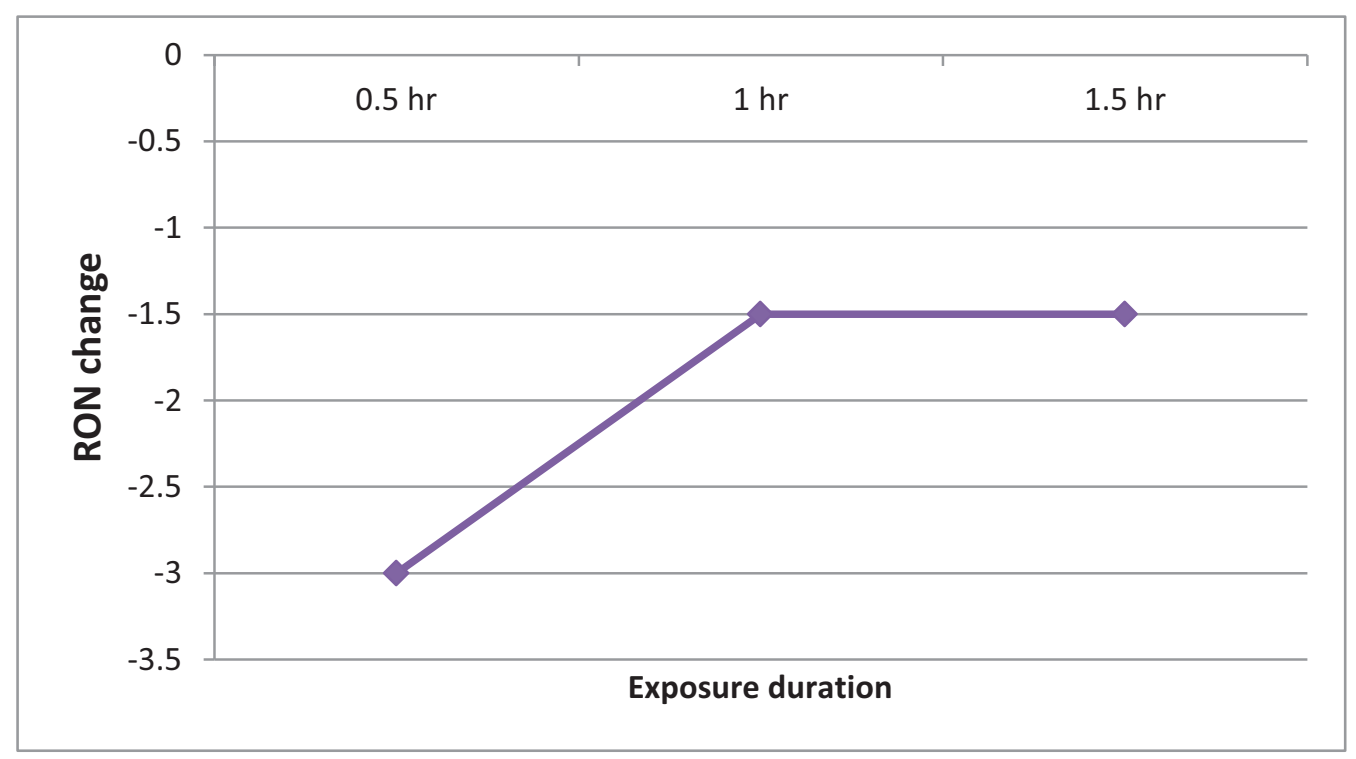

Fig. (14) Results of naphtha exposed to $\mathrm{UV}$ rays with cooling, $\mathrm{ZnO}$ catalyst \& $(2.1 \mathrm{ml} / \mathrm{min}) \mathrm{O}_{2}$ in the cell unit.

Table (5) Results of naphtha exposed to UV rays with cooling, $\mathrm{ZnO}$ catalyst \& $(2.1 \mathrm{ml} / \mathrm{min}) \mathrm{O}_{2}$ in the cell unit.

\begin{tabular}{|c|c|c|c|c|c|c|c|}
\hline \multirow[t]{2}{*}{ Conditions of test } & \multirow{2}{*}{$\begin{array}{c}\text { Time of } \\
\text { test } \\
\text { (hr) }\end{array}$} & \multirow{2}{*}{$\begin{array}{c}\text { Pressure } \\
\text { increase } \\
\text { (bar) }\end{array}$} & \multicolumn{2}{|c|}{$\begin{array}{c}\text { Temperature } \\
\left(\mathrm{C}^{\circ}\right)\end{array}$} & \multirow{2}{*}{$\begin{array}{c}\text { RON } \\
\text { before } \\
\text { test }\end{array}$} & \multirow{2}{*}{$\begin{array}{l}\text { RON } \\
\text { after } \\
\text { test }\end{array}$} & \multirow[t]{2}{*}{$\begin{array}{l}\text { RON } \\
\text { change }\end{array}$} \\
\hline & & & $\begin{array}{c}\text { Before } \\
\text { test }\end{array}$ & $\begin{array}{c}\text { After } \\
\text { test }\end{array}$ & & & \\
\hline \multirow{3}{*}{$\begin{array}{l}\text { Naphtha exposed to UV } \\
\text { lamp of }\left(75 \mathrm{~W} / \mathrm{m}^{2}\right) \text { with } \\
\text { cooling, } \mathrm{ZnO} \text { catalyst \& } \\
(2.1 \mathrm{ml} / \mathrm{min}) \mathrm{O}_{2} .\end{array}$} & 0.5 & 0 & 25 & 25 & 51.2 & 48.2 & -3 \\
\hline & 1 & 0 & 25 & 25 & 51.2 & 49.7 & -1.5 \\
\hline & 1.5 & 0 & 25 & 25 & 51.2 & 49.7 & -1.5 \\
\hline
\end{tabular}




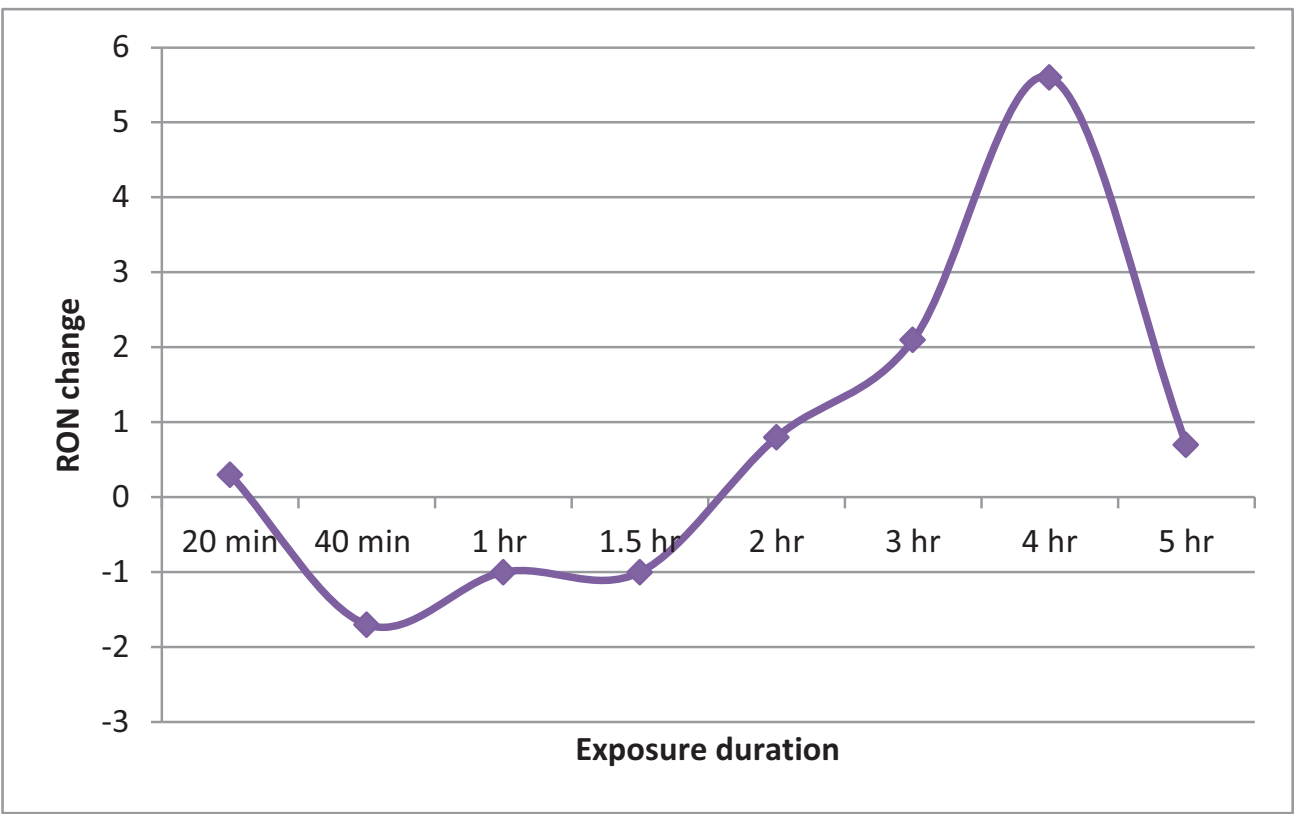

Fig. (15) Results of naphtha exposed to $\mathrm{UV}$ rays with $\mathrm{ZnO}$ catalyst \& $(2.1 \mathrm{ml} / \mathrm{min}) \mathrm{O}_{2}$ in the cell unit.

Table (6) Results of naphtha exposed to $\mathrm{UV}$ rays with $\mathrm{ZnO}$ catalyst $\&(2.1 \mathrm{ml} / \mathrm{min}) \mathrm{O}_{2}$ in the cell unit.

\begin{tabular}{|c|c|c|c|c|c|c|c|}
\hline \multirow[t]{2}{*}{ Conditions of test } & \multirow[t]{2}{*}{$\begin{array}{c}\text { Time of } \\
\text { test }\end{array}$} & \multirow{2}{*}{$\begin{array}{c}\text { Pressure } \\
\text { increase } \\
\text { (bar) }\end{array}$} & \multicolumn{2}{|c|}{$\begin{array}{c}\text { Temperature } \\
\qquad\left(\mathrm{C}^{\circ}\right)\end{array}$} & \multirow{2}{*}{$\begin{array}{c}\text { RON } \\
\text { before } \\
\text { test }\end{array}$} & \multirow{2}{*}{$\begin{array}{l}\text { RON } \\
\text { after } \\
\text { test }\end{array}$} & \multirow[t]{2}{*}{$\begin{array}{l}\text { RON } \\
\text { change }\end{array}$} \\
\hline & & & $\begin{array}{c}\text { Before } \\
\text { test }\end{array}$ & $\begin{array}{c}\text { After } \\
\text { test }\end{array}$ & & & \\
\hline \multirow{8}{*}{$\begin{array}{l}\text { Naphtha exposed to UV } \\
\text { lamp of }\left(75 \mathrm{~W} / \mathrm{m}^{2}\right) \text { with } \\
\mathrm{ZnO} \text { catalyst \& }(2.1 \\
\mathrm{ml} / \mathrm{min}) \mathrm{O}_{2} .\end{array}$} & $20 \mathrm{~min}$ & 0 & 25.5 & 26 & 51.2 & 51.5 & +0.3 \\
\hline & $40 \mathrm{~min}$ & 0 & 25.5 & 26.6 & 51.2 & 49.5 & -1.7 \\
\hline & $1 \mathrm{hr}$ & 0 & 25.5 & 27.1 & 51.2 & 50.2 & -1 \\
\hline & $1.5 \mathrm{hr}$ & 0 & 25.5 & 27.7 & 51.2 & 50.2 & -1 \\
\hline & $2 \mathrm{hr}$ & 0 & 25.5 & 28.1 & 51.2 & 52.0 & +0.8 \\
\hline & $3 \mathrm{hr}$ & 0 & 25.5 & 28.7 & 51.2 & 53.3 & +2.1 \\
\hline & $4 \mathrm{hr}$ & 0 & 25.5 & 29.4 & 51.2 & 56.8 & +5.6 \\
\hline & $5 \mathrm{hr}$ & 0 & 25.5 & 29.9 & 51.2 & 51.9 & +0.7 \\
\hline
\end{tabular}




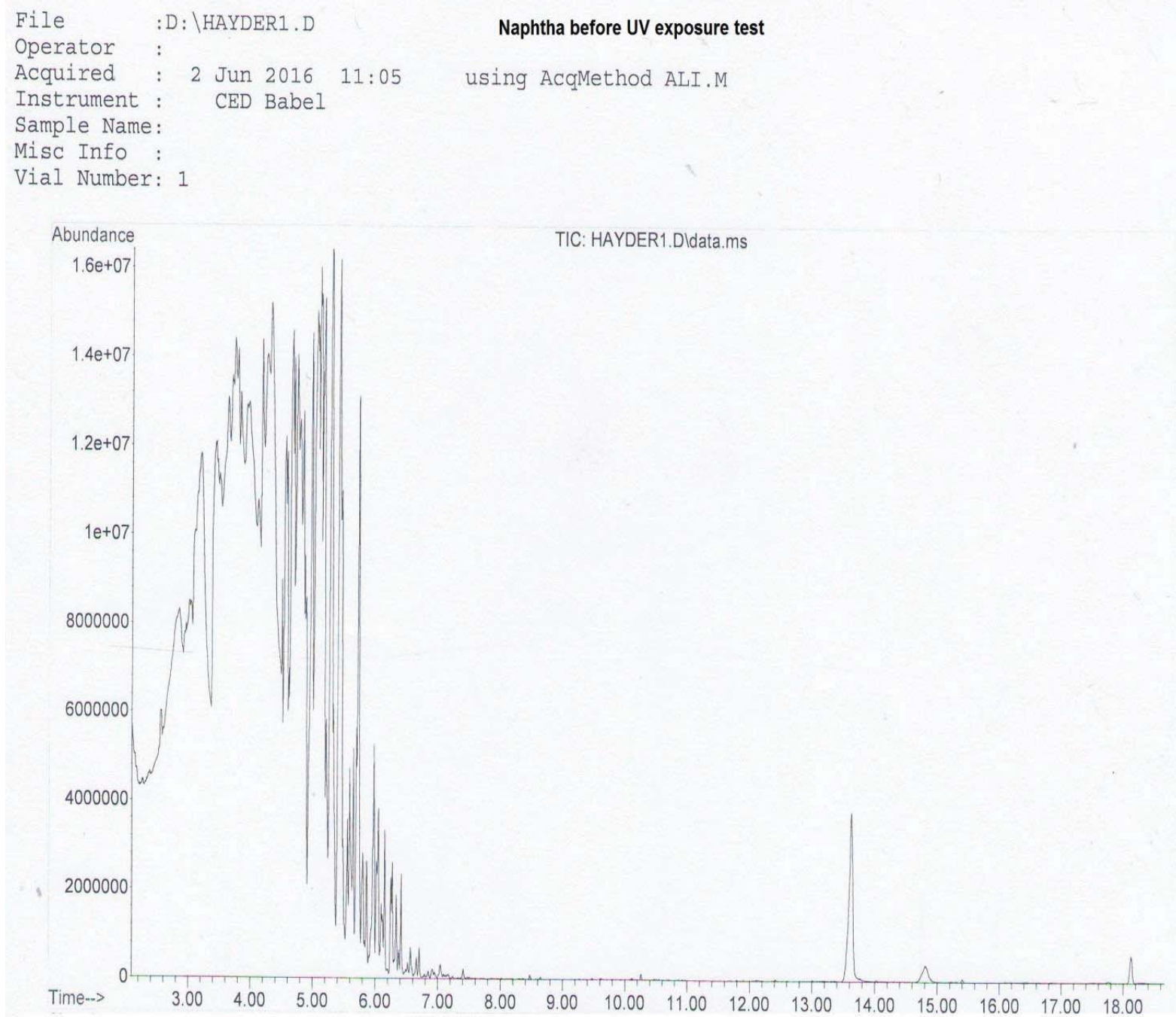

Fig. (16) GCMS Curve Of Sample Before Test 
Table (7) Area percent report of sample before test

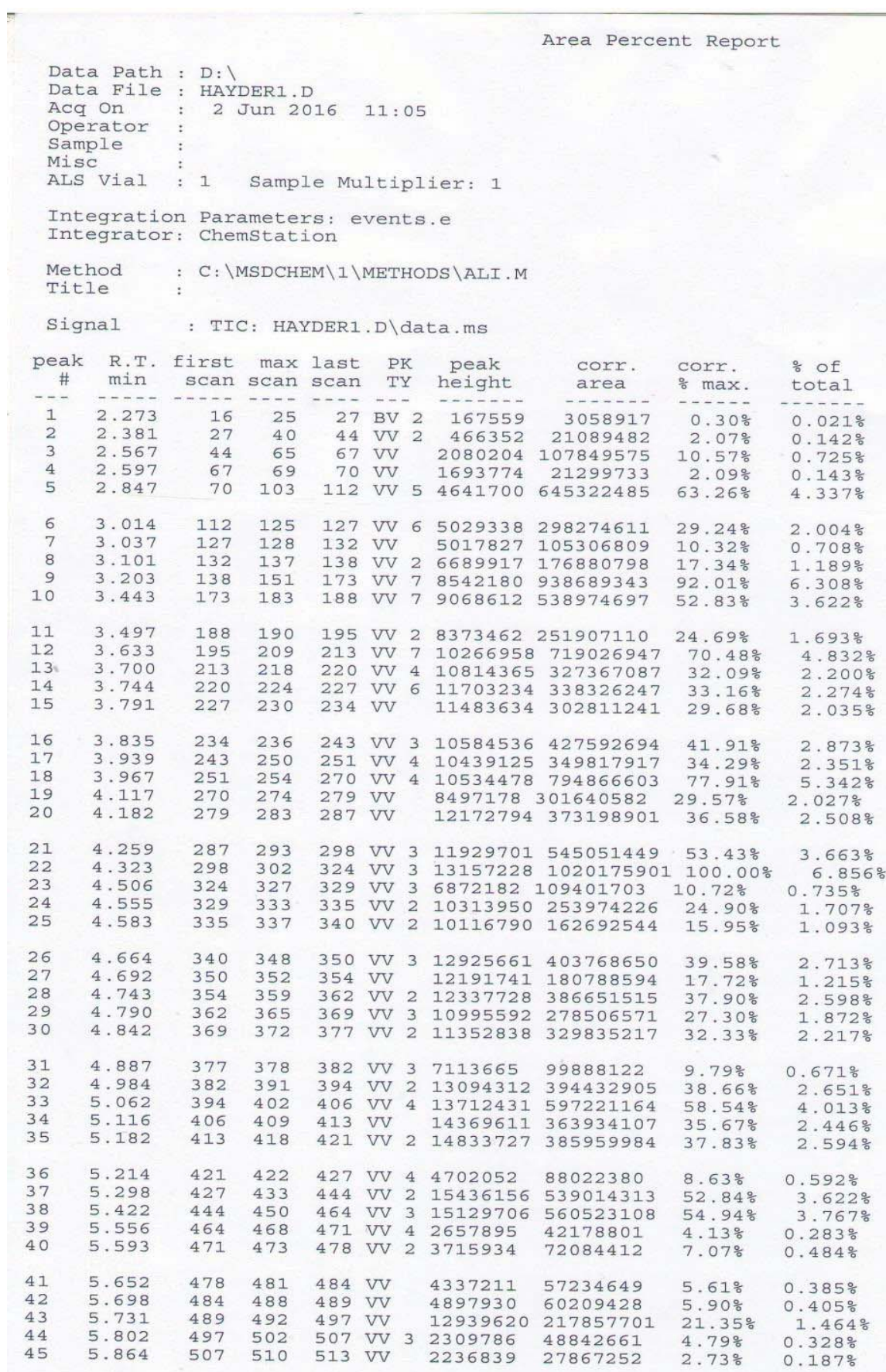




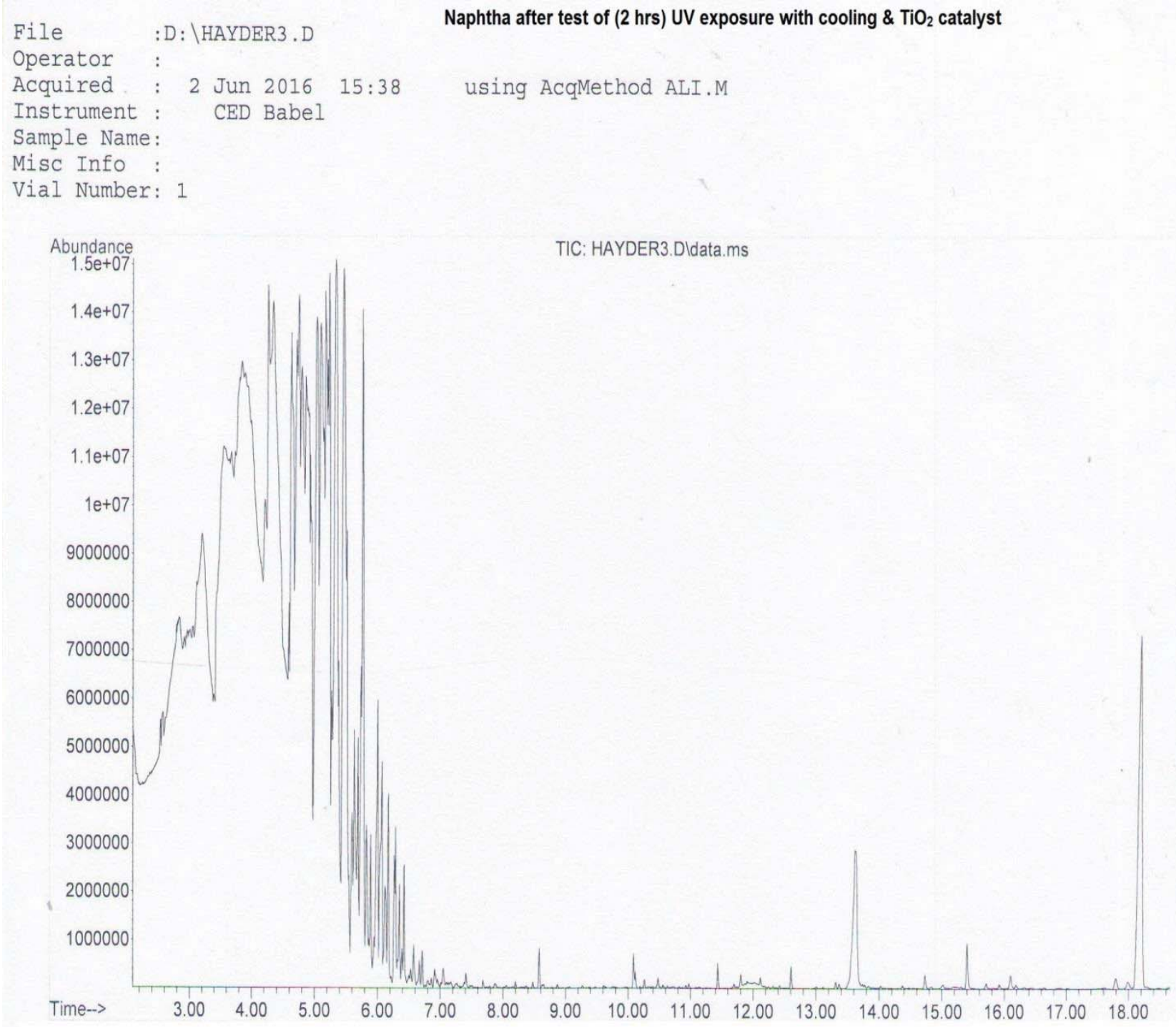

Fig. (17) GCMS Curve Of RON Decreasing Sample After Test 
Table (8) Area Percent Report Of RON Decreasing Sample After Test

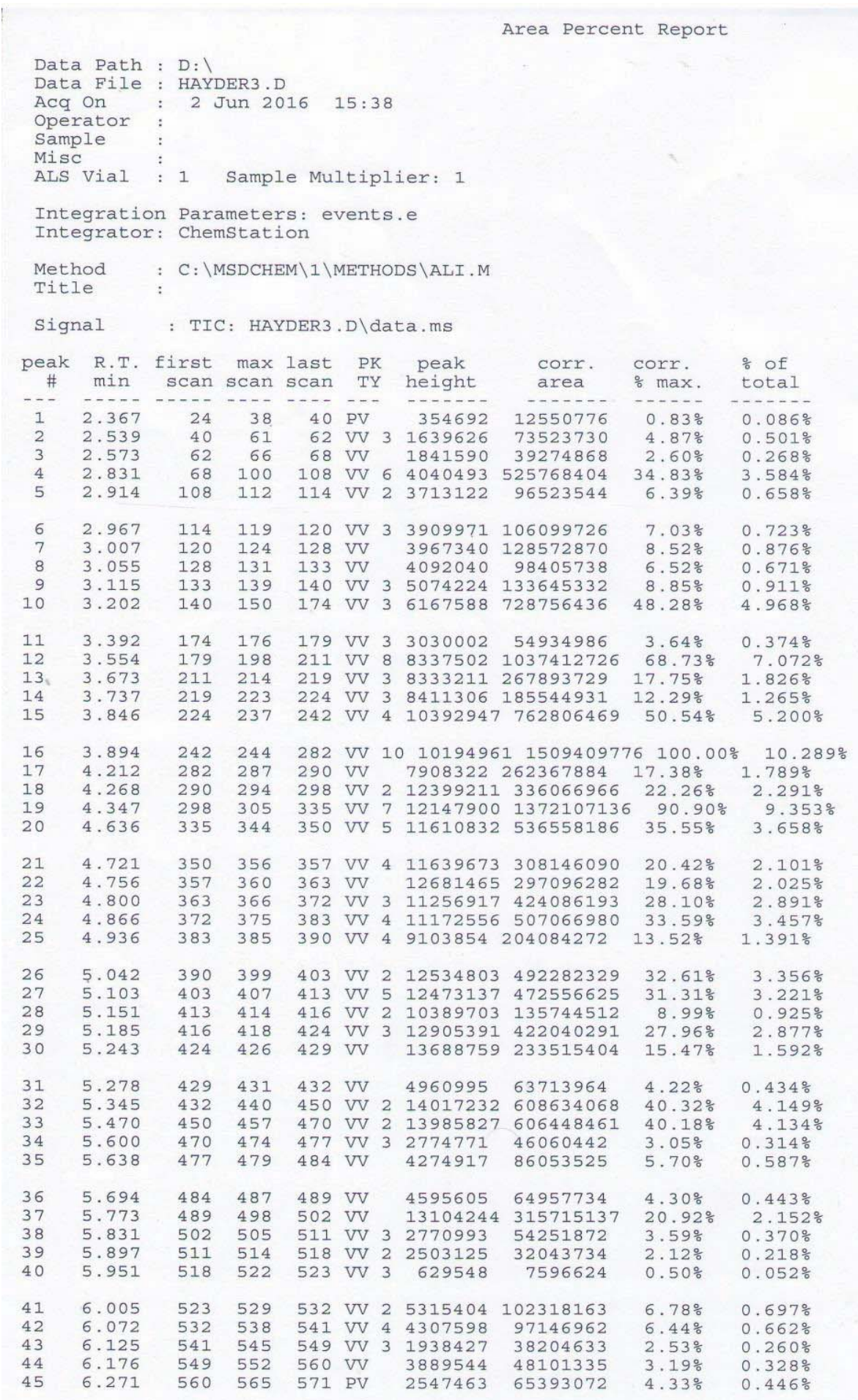


Table (9) The Changes In Percent Of The Effective Compounds According To The GCMS Tests.

\begin{tabular}{|c|c|c|c|c|}
\hline No. & $\begin{array}{c}\text { Effective } \\
\text { compound }\end{array}$ & $\begin{array}{c}\text { Retention time } \\
(\mathrm{min})\end{array}$ & $\begin{array}{c}\text { Percentage before } \\
\text { test } \%\end{array}$ & $\begin{array}{c}\text { Percentage } \\
\text { after test } \%\end{array}$ \\
\hline 1 & Isooctane & 3.347 & 0 & 0.374 \\
\hline 2 & Benzene & 4.724 & 2.598 & 2.101 \\
\hline 3 & Toluene & 3.021 & 0.708 & 0.876 \\
\hline 4 & P-xylene & 4.154 & 2.508 & 0 \\
\hline
\end{tabular}

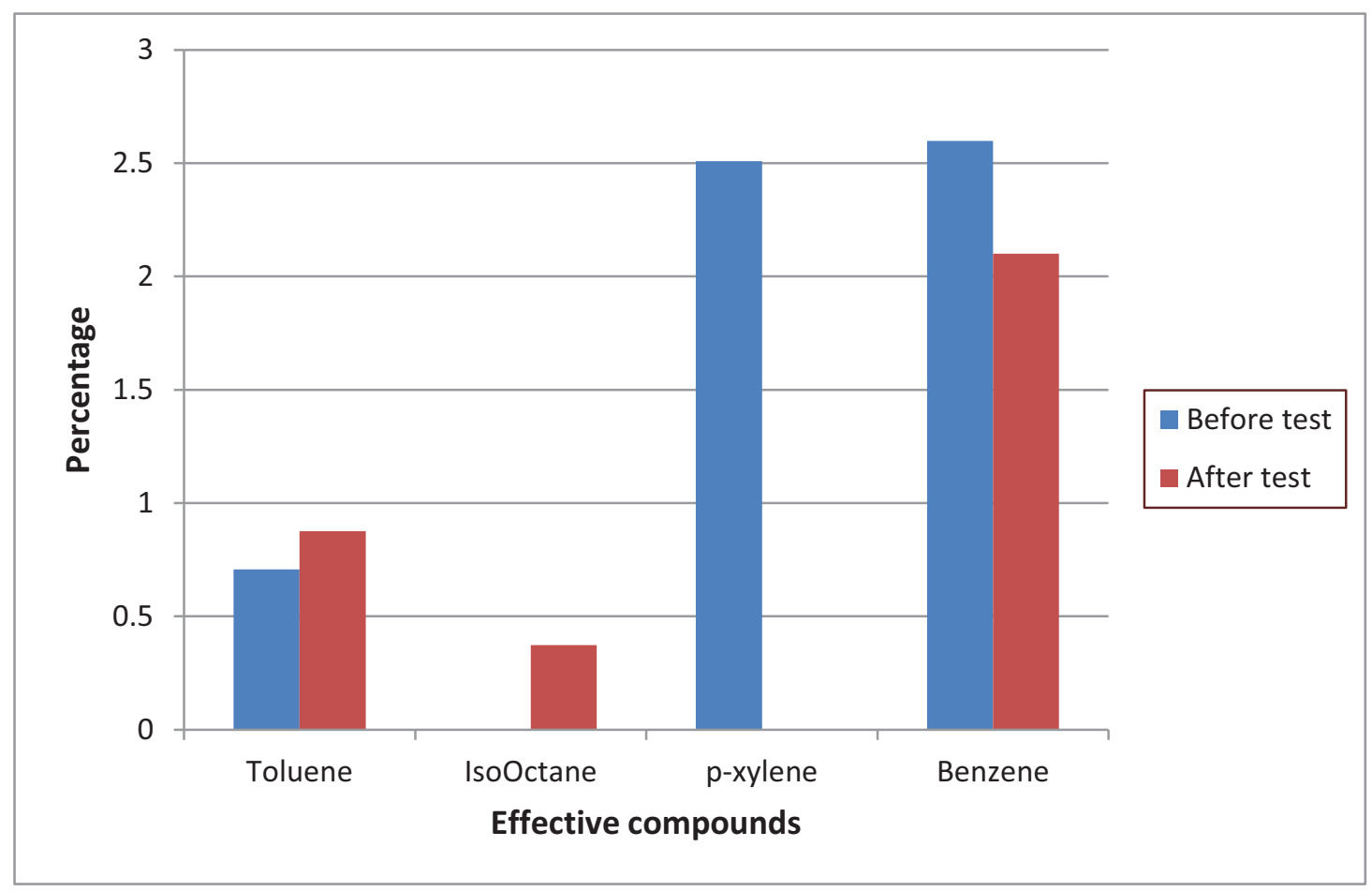

Fig. (18) The Changes In Percents Of The Effective Compounds According To The GCMS Tests.

Table (10) RON Of The Important Aromatic Compounds And Isooctane [17].

\begin{tabular}{|c|c|}
\hline Compound & RON \\
\hline Isooctane & 100 \\
\hline Benzene & 99 \\
\hline Toluene & 124 \\
\hline P-xylene & 146 \\
\hline
\end{tabular}



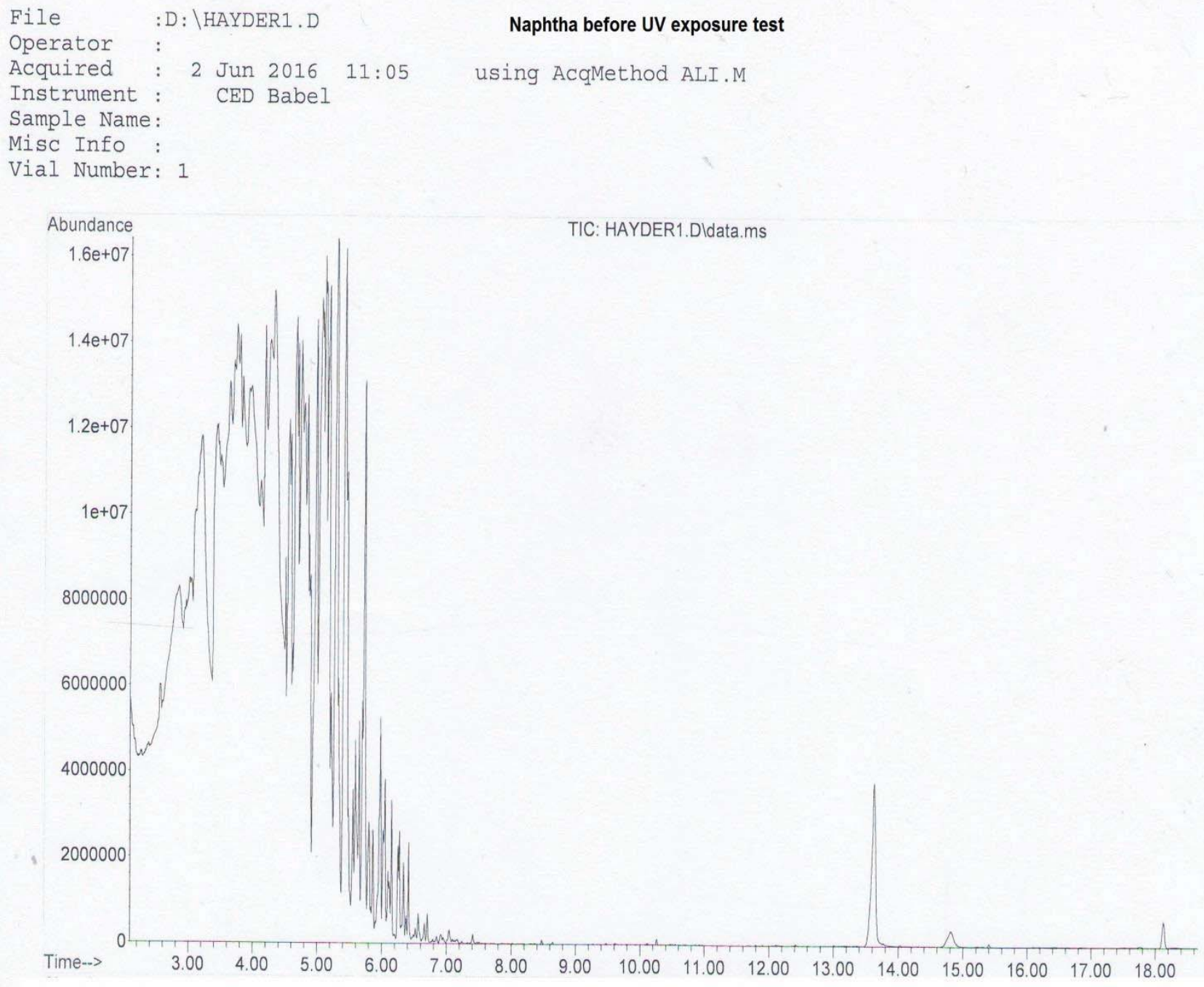

Fig. (19) GCMS curve of sample before test 
Table (11) Area percent report of sample before test

\begin{tabular}{|c|c|c|c|c|c|c|c|c|c|}
\hline \multicolumn{2}{|c|}{$\begin{array}{l}\text { Data Path } \\
\text { Data File } \\
\text { Acq on } \\
\text { Operator } \\
\text { Sample } \\
\text { Misc } \\
\text { ALS Vial }\end{array}$} & 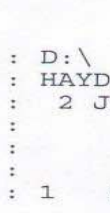 & R. 20 & $=$ Mul & $11: 05$ & ier: 1 & Area Percen & nt Report & \\
\hline \multicolumn{10}{|c|}{$\begin{array}{l}\text { Integration Parameters: events.e } \\
\text { Integrator: Chemstation }\end{array}$} \\
\hline \multicolumn{2}{|c|}{$\begin{array}{l}\text { Method } \\
\text { Title }\end{array}$} & \multicolumn{8}{|c|}{ : C: $\backslash$ MSDCHEM \I\METHODS \ALI.M } \\
\hline \multicolumn{10}{|c|}{ *. HAYDFP 1 DIdata ma } \\
\hline $\begin{array}{l}\text { eak } \\
\#\end{array}$ & $\begin{array}{l}\text { R.T. } f \\
\text { min }\end{array}$ & $\begin{array}{l}\text { first } \\
\text { scan }\end{array}$ & $\max :$ & $\begin{array}{l}\text { last } \\
\text { scan }\end{array}$ & $\begin{array}{r}\text { PK } \\
\text { TY }\end{array}$ & $\begin{array}{l}\text { peak } \\
\text { height }\end{array}$ & $\begin{array}{l}\text { corr. } \\
\text { area }\end{array}$ & $\begin{array}{l}\text { corr. } \\
\% \max \end{array}$ & $\begin{array}{l}\text { \%of } \\
\text { total }\end{array}$ \\
\hline $\begin{array}{l}1 \\
2 \\
3 \\
4 \\
5\end{array}$ & $\begin{array}{l}2.273 \\
2.381 \\
2.567 \\
2.597 \\
2.847\end{array}$ & $\begin{array}{l}16 \\
27 \\
44 \\
67 \\
70\end{array}$ & $\begin{array}{r}25 \\
40 \\
65 \\
69 \\
103\end{array}$ & $\begin{array}{r}27 \\
44 \\
67 \\
70 \\
112\end{array}$ & $\begin{array}{ll}\text { BV } & 2 \\
\text { VV } & 2 \\
\text { VV } & \\
\text { VV } & \\
\text { VV } & 5\end{array}$ & $\begin{array}{r}167559 \\
466352 \\
2080204 \\
1693774 \\
4641700\end{array}$ & $\begin{array}{r}3058917 \\
21089482 \\
107849575 \\
21299733 \\
645322485\end{array}$ & $\begin{array}{r}0.30 \% \\
2.07 \% \\
10.57 \% \\
2.09 \% \\
63.26 \%\end{array}$ & \\
\hline $\begin{array}{l}6 \\
7 \\
8 \\
9 \\
0\end{array}$ & $\begin{array}{l}3.014 \\
3.037 \\
3.101 \\
3.203 \\
3.443\end{array}$ & $\begin{array}{l}112 \\
127 \\
132 \\
138 \\
173\end{array}$ & $\begin{array}{l}125 \\
128 \\
137 \\
151 \\
183\end{array}$ & $\begin{array}{l}127 \\
132 \\
138 \\
173 \\
188\end{array}$ & $\begin{array}{ll}\text { vV } & 6 \\
\text { Vv } & \\
\text { vV } & 2 \\
\text { vv } & 7 \\
\text { vV } & 7\end{array}$ & $\begin{array}{l}5029338 \\
5017827 \\
6689917 \\
8542180 \\
9068612\end{array}$ & $\begin{array}{ll}298274611 & 2 \\
105306809 & 1 \\
176880798 & 1 \\
938689343 & 9 \\
538974697 & 5\end{array}$ & $\begin{array}{l}17.34 \% \\
92.01 \% \\
52.83 \%\end{array}$ & \\
\hline & $\begin{array}{l}3.497 \\
3.633 \\
3.700 \\
3.744 \\
3.791\end{array}$ & $\begin{array}{l}188 \\
195 \\
213 \\
220 \\
227\end{array}$ & $\begin{array}{l}190 \\
209 \\
218 \\
224 \\
230\end{array}$ & $\begin{array}{l}195 \\
213 \\
220 \\
227 \\
234\end{array}$ & $\begin{array}{ll}\text { Vv } & 2 \\
\text { Vv } & 7 \\
\text { vv } & 4 \\
\text { vv } & 6 \\
\text { vv } & \end{array}$ & $\begin{array}{l}83734622 \\
10266958 \\
10814365 \\
11703234 \\
11483634\end{array}$ & $\begin{array}{l}251907110 \\
719026947 \\
327367087 \\
338326247 \\
302811241\end{array}$ & $\begin{array}{r}24.69 \% \\
70.48 \% \\
32.09 \% \\
33.16 \% \\
29.68 \%\end{array}$ & $\begin{array}{r}1.693 \% \\
4.832 \% \\
2.200 \% \\
2.274 \% \\
2.035 \%\end{array}$ \\
\hline & $\begin{array}{l}3.835 \\
3.939 \\
3.967 \\
4.117 \\
4.182\end{array}$ & $\begin{array}{l}234 \\
243 \\
251 \\
270 \\
279\end{array}$ & $\begin{array}{l}236 \\
250 \\
254 \\
274 \\
283\end{array}$ & $\begin{array}{l}243 \\
251 \\
270 \\
279 \\
287\end{array}$ & $\begin{array}{ll}\text { VV } & 3 \\
\text { VV } & 4 \\
\text { Vv } & 4 \\
\text { Vv } \\
\text { Vv }\end{array}$ & $\begin{array}{l}10584536 \\
10439125 \\
10534778 \\
8497178 \\
12172794\end{array}$ & & $\begin{array}{r}41.91 \% \\
34.29 \% \\
77.91 \% \\
29.57 \% \\
36.58 \%\end{array}$ & $\begin{array}{r}2.873 \% \\
2.351 \% \\
5.342 \% \\
2.027 \% \\
2.508 \%\end{array}$ \\
\hline & $\begin{array}{l}4.259 \\
4.323 \\
4.506 \\
4.555 \\
4.583\end{array}$ & $\begin{array}{l}287 \\
298 \\
324 \\
329 \\
335\end{array}$ & & $\begin{array}{l}298 \\
324 \\
329 \\
335 \\
340\end{array}$ & $\begin{array}{ll}\text { VV } & 3 \\
\text { Vv } & 3 \\
\text { Vv } & 3 \\
\text { vV } & 2 \\
\text { vV } & 2\end{array}$ & $\begin{array}{l}11929701 \\
13157228 \\
6872182 \\
10313950 \\
10116790\end{array}$ & $\begin{array}{c}545051449 \\
1020175901 \\
109401703 \\
253974226 \\
162692544\end{array}$ & $\begin{array}{l}53.43 \% \\
100.00 \% \\
10.72 \% \\
24.90 \% \\
15.95 \%\end{array}$ & $\begin{array}{r}3.663 \% \\
6.856 \\
0.735 \% \\
1.707 \% \\
1.093 \%\end{array}$ \\
\hline & $\begin{array}{l}4.664 \\
4.692 \\
4.743 \\
4.790 \\
4.842\end{array}$ & $\begin{array}{l}340 \\
350 \\
354 \\
362 \\
369\end{array}$ & $\begin{array}{l}348 \\
352 \\
359 \\
365 \\
372\end{array}$ & $\begin{array}{l}350 \\
354 \\
362 \\
369 \\
377\end{array}$ & $\begin{array}{lll}\text { Vv } & 3 & 1 \\
\text { Vv } & 3 \\
\text { vv } & 2 & 3 \\
\text { vv } & 3 & 3 \\
\text { vv } & 2 & 3\end{array}$ & & $\begin{array}{l}403768650 \\
180788594 \\
386651515 \\
278506571 \\
329835217\end{array}$ & $32.33 \%$ & \\
\hline & $\begin{array}{l}5.062 \\
5.116 \\
5.182\end{array}$ & & & $\begin{array}{l}82 \\
94 \\
06 \\
13 \\
21\end{array}$ & $\begin{array}{lll}\text { vV } & 3 & \\
\text { vV } & 2 & 1 \\
\text { Vv } & 4 & 1 \\
\text { VV } & 1 \\
\text { Vv } & 2 & 1\end{array}$ & & & $\begin{array}{l}35.67 \% \\
37.83 \%\end{array}$ & $\begin{array}{l}0.671 \% \\
2.651 \% \\
4.013 \% \\
2.446 \% \\
2.594 \%\end{array}$ \\
\hline & $\begin{array}{l}5.214 \\
5.298 \\
5.422 \\
5.556 \\
5.593\end{array}$ & $\begin{array}{l}421 \\
427 \\
444 \\
464 \\
471\end{array}$ & $\begin{array}{l}468 \\
473\end{array}$ & $\left.\begin{array}{l}427 \\
444 \\
464 \\
471 \\
478\end{array}\right)$ & $\begin{array}{lll}\text { VV } & 4 & 4 \\
\text { vV } & 2 & 1 \\
\text { vV } & 3 & 1 \\
\text { vV } & 4 & 2 \\
\text { vv } & 2 & 3\end{array}$ & $\begin{array}{l}4702052 \\
15436156 \\
15129706 \\
2657895 \\
3715934\end{array}$ & $\begin{array}{l}88022380 \\
539014313 \\
560523108 \\
42178801 \\
72084412\end{array}$ & $\begin{array}{l}8.63 \% \\
52.84 \% \\
54.94 \% \\
4.13 \% \\
7.07 \%\end{array}$ & $\begin{array}{l}0.592 \% \\
3.622 \% \\
3.767 \% \\
0.283 \% \\
0.484 \%\end{array}$ \\
\hline & $\begin{array}{l}5.698 \\
5.731 \\
5.802 \\
5.864\end{array}$ & $\begin{array}{l}484 \\
489 \\
497 \\
507\end{array}$ & $\begin{array}{l}502 \\
510 \\
510\end{array}$ & $\begin{array}{l}484 \\
489 \\
497 \\
507 \\
513\end{array}$ & 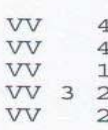 & $\begin{array}{l}4897930 \\
12939620 \\
2309786 \\
2236839\end{array}$ & $\begin{array}{l}57234649 \\
60209428 \\
21785701 \\
48842661 \\
27867252\end{array}$ & $\begin{array}{l}5.61 \% \\
5.90 \% \\
21.35 \% \\
4.79 \% \\
2.73 \%\end{array}$ & $\begin{array}{l}0.385 \% \\
0.405 \% \\
1.464 \% \\
0.328 \% \\
0.187 \%\end{array}$ \\
\hline
\end{tabular}




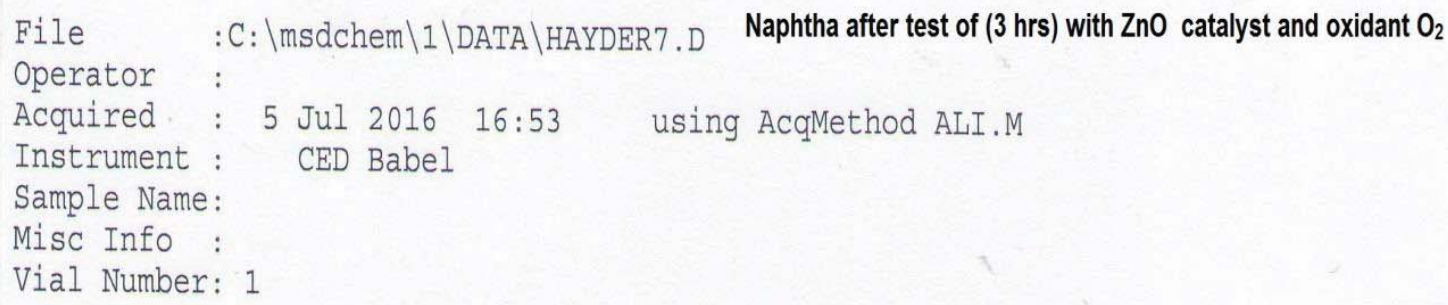

Vial Number: 1

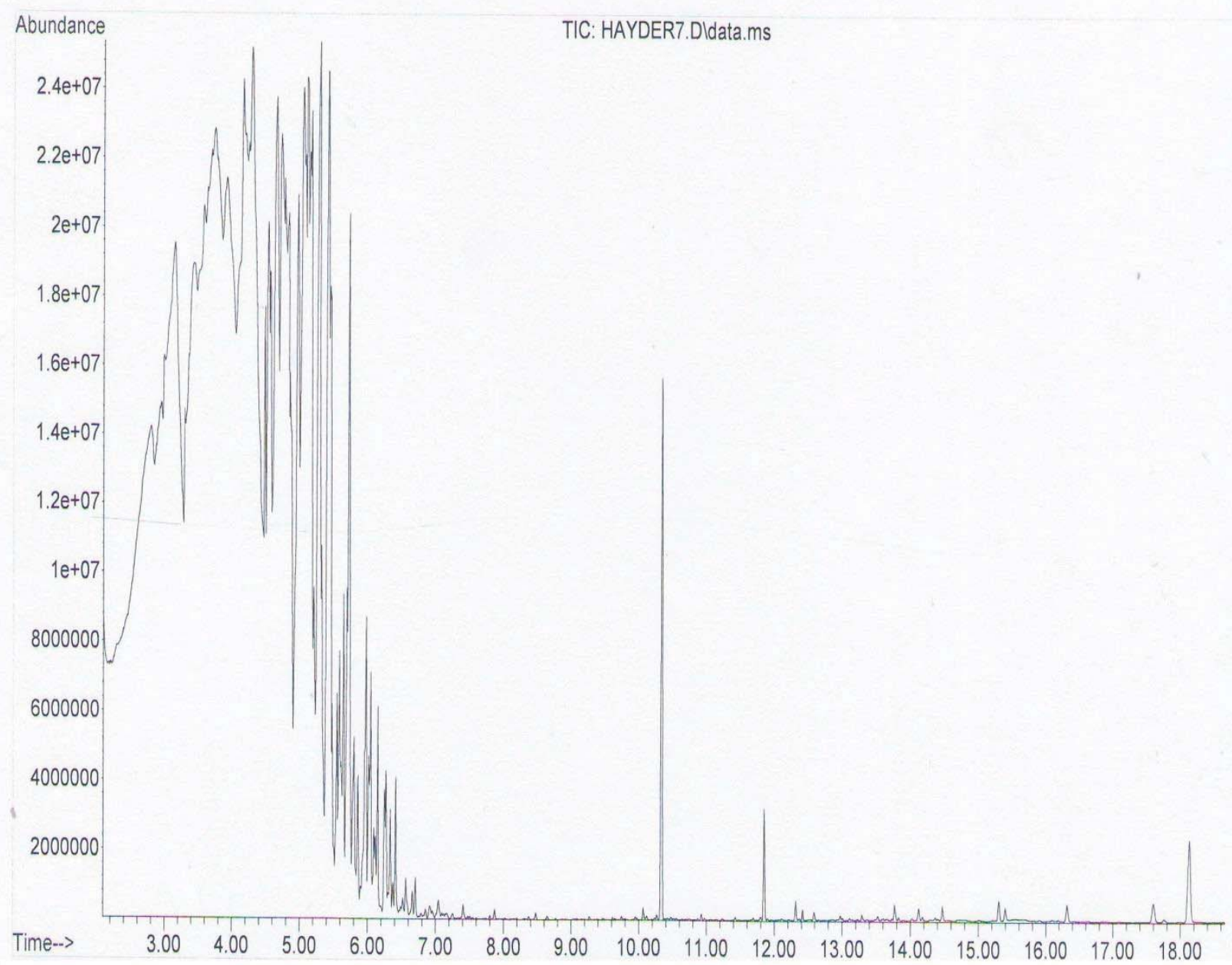

Fig. (20) GCMS curve of RON increasing sample after test 
Table (12) Area percent report of RON increasing sample after test

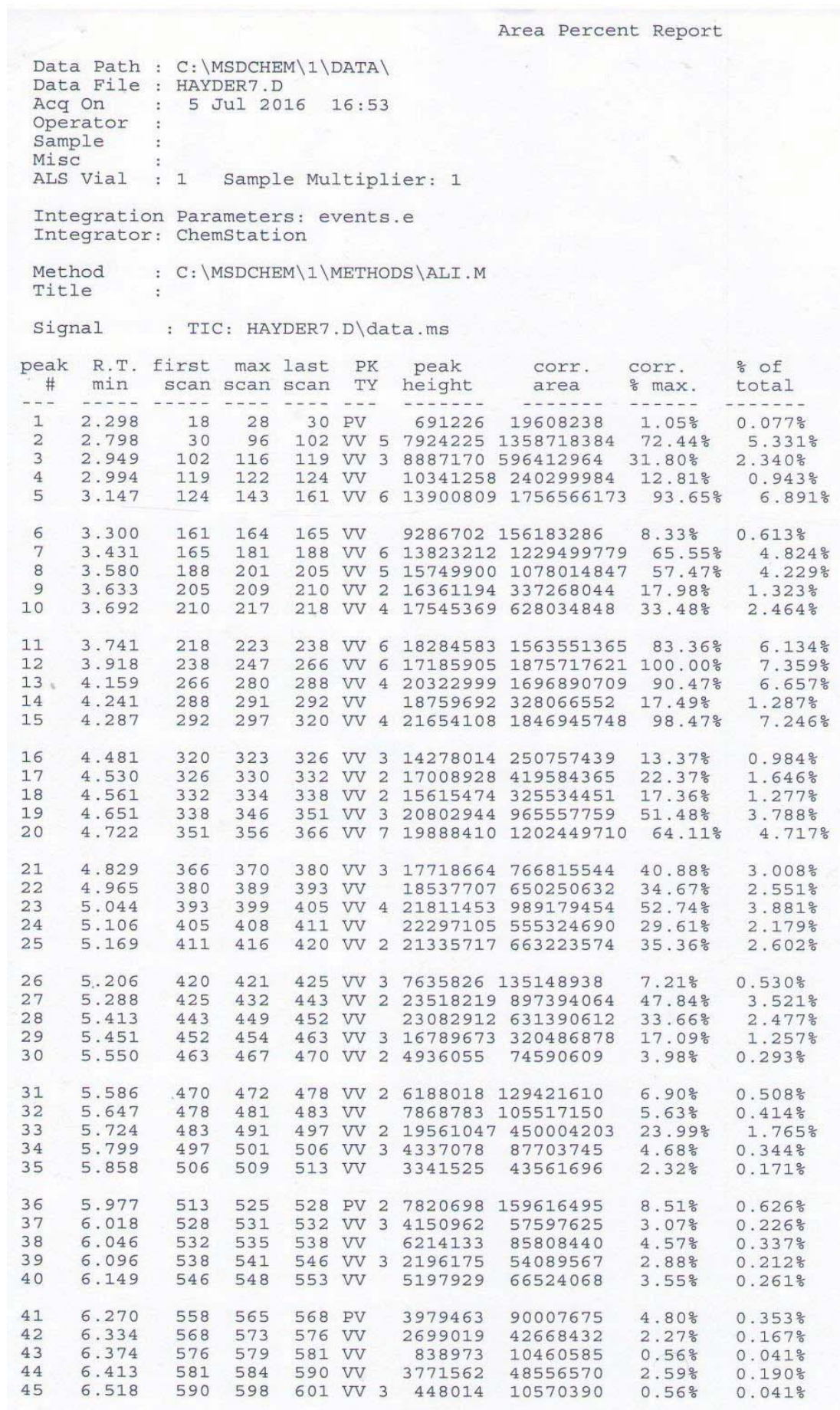


Table (13) The changes in percents of the effective compounds according to the GCMS tests.

\begin{tabular}{|c|c|c|c|c|}
\hline No. & $\begin{array}{c}\text { Effective } \\
\text { compound }\end{array}$ & $\begin{array}{c}\text { Retention time } \\
(\mathrm{min})\end{array}$ & $\begin{array}{c}\text { Percentage } \\
\text { before test \% }\end{array}$ & $\begin{array}{c}\text { Percentage } \\
\text { after test \% }\end{array}$ \\
\hline 1 & IsoOctane & 3.347 & 0 & 0.613 \\
\hline 2 & Benzene & 4.724 & 2.598 & 4.717 \\
\hline 3 & Toluene & 3.021 & 0.708 & 0 \\
\hline 4 & P-xylene & 4.154 & 2.508 & 6.657 \\
\hline
\end{tabular}

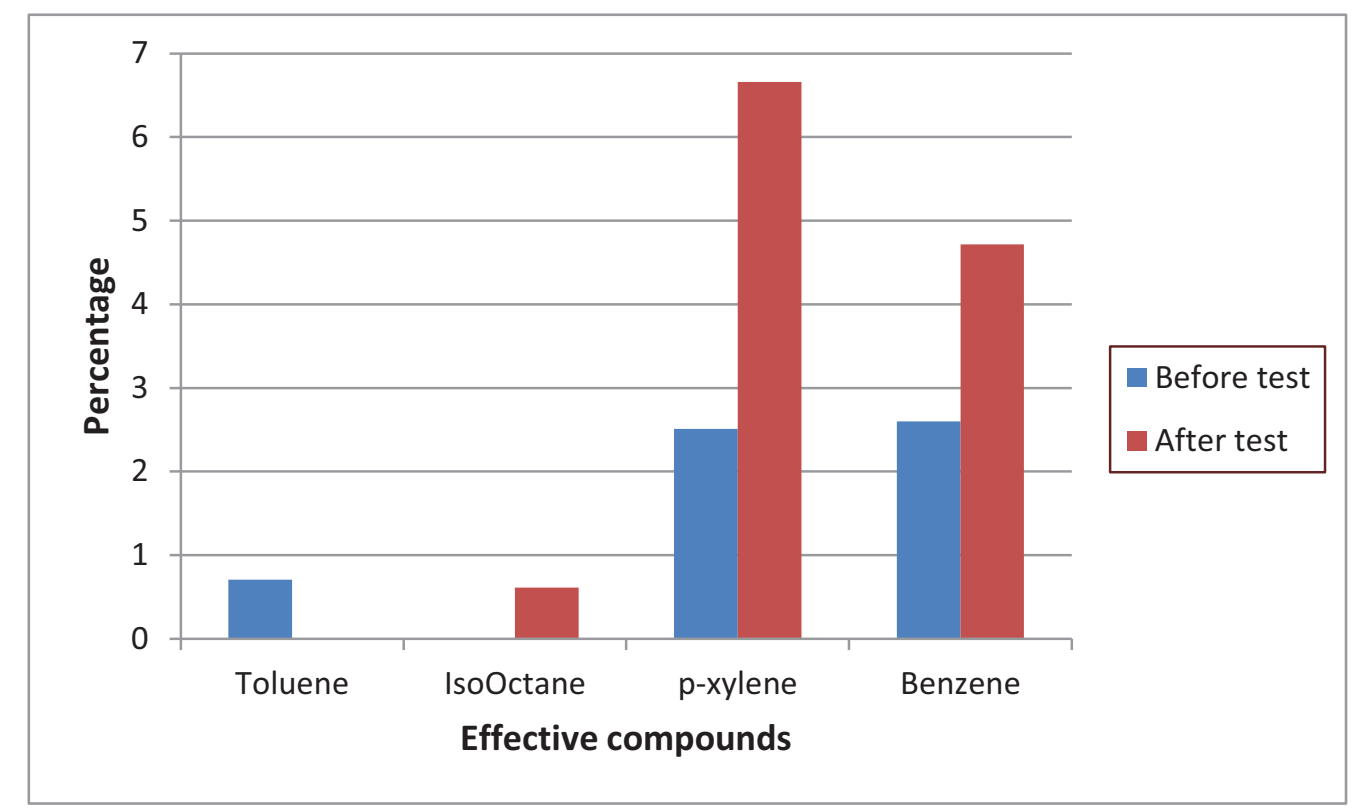

Fig. (21) The changes in percents of the effective compounds according to the GCMS tests. 


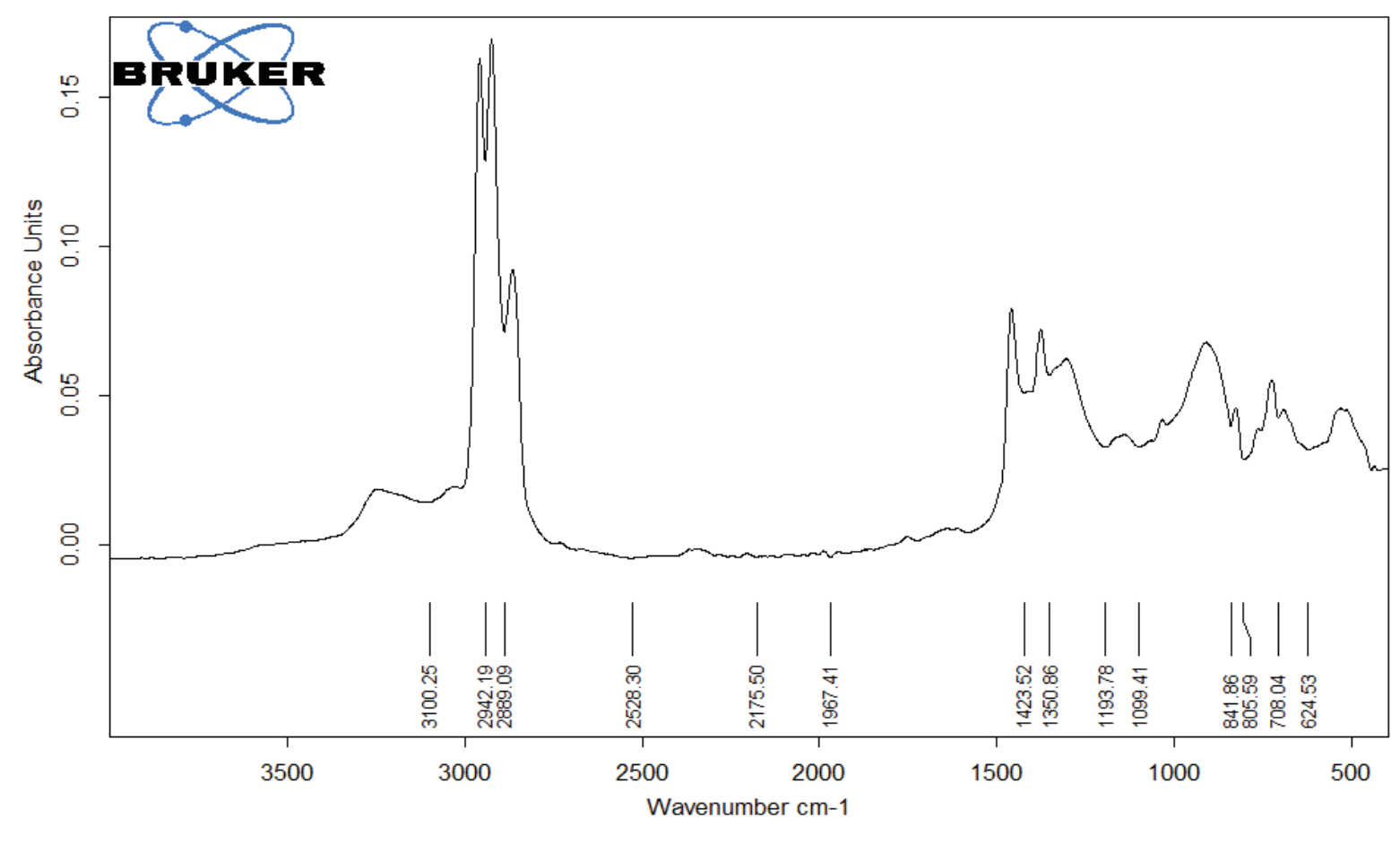

Fig. (22) FTIR Curve of RON increasing sample before test

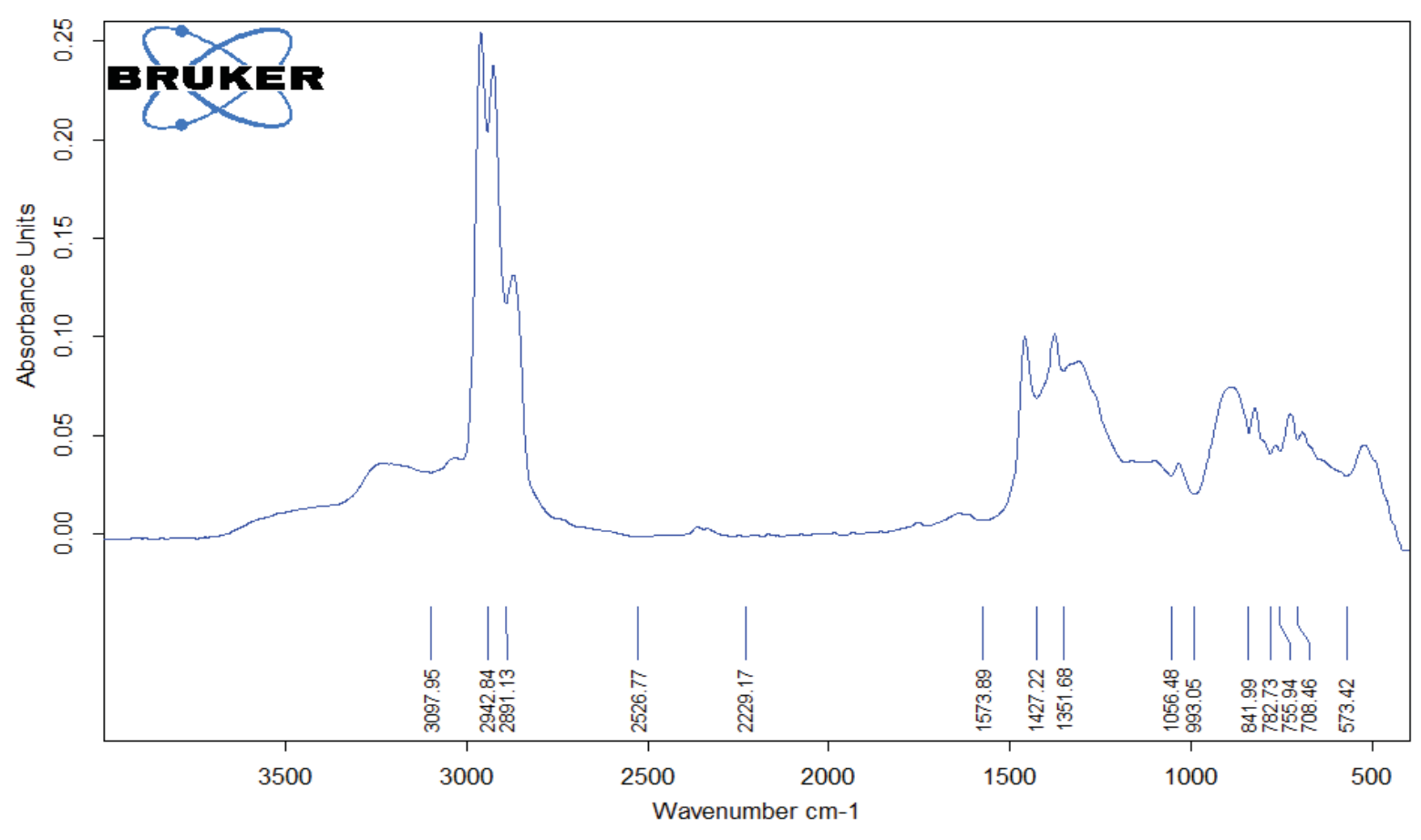

Fig. (23) FTIR Curve Of RON Decreasing Sample After Test 
No.19 Journal of Petroleum Research \& Studies

(JPR\&S)

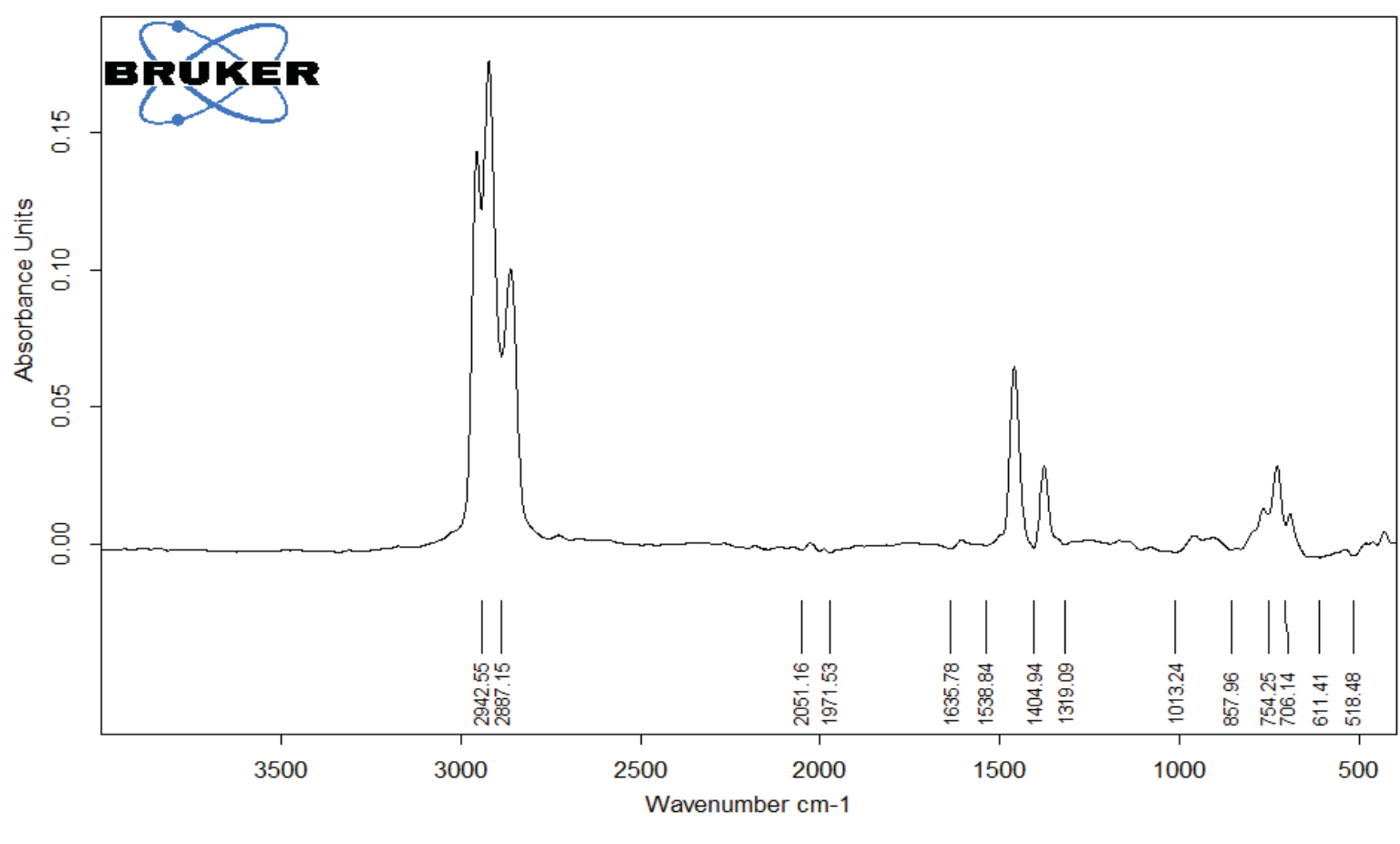

Fig. (24) FTIR curve of RON increasing sample after test 